\title{
PARP1 during embryo implantation and its upregulation by oestradiol in mice
}

\author{
Anubha Joshi ${ }^{1}$, Sahil Mahfooz ${ }^{1}$, Vineet Kumar Maurya ${ }^{1}$, Vijay Kumar ${ }^{1}$, \\ Chadchan Sangappa Basanna ${ }^{1}$, Gurpreet Kaur ${ }^{2}$, Kashif Hanif ${ }^{2}$ and Rajesh Kumar Jha ${ }^{1}$ \\ ${ }^{1}$ Division of Endocrinology, Life Science North 111B/101 and ${ }^{2}$ Division of Pharmacology, Preclinical South 201, \\ CSIR-Central Drug Research Institute, B.S. 10/1, Sector-10, Jankipuram Extension, Sitapur Road, \\ Lucknow 226031, India
}

Correspondence should be addressed to R K Jha; Email: rajesh_jha@cdri.res.in; http://www.cdriindia.org/rdivision5.htm

\begin{abstract}
Pregnancy requires successful implantation of an embryo, which occurs during a restricted period defined as 'receptivity of the endometrium' and is influenced by the ovarian steroids progesterone and oestradiol. The role of poly(ADP-ribose)polymerase-1 (PARP1) in apoptosis is well established. However, it is also involved in cell differentiation, proliferation and tissue remodelling. Previous studies have described the presence of PARP in the uterus, but its exact role in embryo implantation is not yet elucidated. Hence, in this study, we studied the expression of PARP1 in the uterus during embryo implantation and decidualisation, and its regulation by ovarian steroids. Our results show upregulation of the native form of PARP1 ( 116 kDa) in the cytosolic and nuclear compartments of implantation and non-implantation sites at day $5(0500 \mathrm{~h})$, followed by downregulation at day $5(1000 \mathrm{~h})$, during the embryo implantation period. The transcript level of Parp1 was also augmented during day $5(0500 \mathrm{~h})$. Inhibition of PARP1 activity by the drug EB-47 decreased the number of embryo implantation sites and blastocysts at day $5(\mathbf{1 0 0 0} \mathrm{h})$. Further, cleavage of native PARP1 was due to the activity of caspase-3 during the peri-implantation stage (day $5(0500 \mathrm{~h})$ ), and is also required for embryo implantation, as inhibition of its activity compromised blastocyst implantation. The native $(\sim 116 \mathrm{kDa})$ and cleaved $(\sim 89 \mathrm{kDa})$ forms of PARP1 were both elevated during decidualisation of the uterus. Furthermore, the expression level of PARP1 in the uterus was found to be under the control of the hormone oestrogen. Our results clearly demonstrate that PARP1 participates in the process of embryo implantation.

Reproduction (2014) 147 765-780
\end{abstract}

\section{Introduction}

In mammals, embryonic development takes place in the uterus, requiring the implantation of an embryo in a specific time frame known as the window of uterine receptivity. In this period, the uterus acquires maximal receptivity for the implantation of the blastocysts (Duc-Goiran et al. 1999). During implantation, uterus and embryo synchronise for their intimate interaction (Burghardt et al. 2002). The endometrium undergoes many morphological changes, including cell proliferation, differentiation and apoptosis, to provide the best environment for implantation of the embryo (Demir et al. 2002, Joswig et al. 2003, Correia-da-Silva et al. 2004). However, when embryo implantation occurs, many changes begin in the endometrium, where stromal cells proliferate in response to oestrogen and progesterone to form the decidual cells, a process called decidualisation (Dey et al. 2004, Lei et al. 2012). Poly(ADP-ribose) polymerase (PARP) is reported to be linked with the tissue remodelling process (Pagano et al. 2007), which has already been studied in the uterus (Ghabreau et al. 2004, Brustmann 2007, Postawski et al. 2011). Furthermore, the double mutation of both ataxia-telangiectasia (Atm) and Parp1 genes in the mouse leads to an early post-implantation lethality of the embryo at embryonic day 8.0 (E8.0), with extensive cell death in the embryo at E11.5 (Menisser-de et al. 2001). These studies suggest a possible role of PARP in the reproduction process.

Although PARP1 is a hallmark of apoptosis, it is also reported to be involved in other cellular signalling, e.g. expression of adhesion molecules (von Lukowicz et al. 2008), transcriptional regulation of cyclooxygenase-2 (Lin et al. 2011), transforming growth factor- $\beta 1$ (TGF- $\beta 1$ ) receptor (Sterling et al. 2006), syndecan-4 (Lacal et al. 2009), NF-KB (Kauppinen et al. 2013), SMAD3 (Huang et al. 2011), sex determining region Y-Box-2 (Musard et al. 2001) and E-cadherin (McPhee et al. 2008), which are essential during embryo implantation (Nakamura et al. 2004, San et al. 2004, Jha et al. 2006, Lin et al. 2006, St-Louis et al. 2010). Furthermore, cell differentiation, cell 
proliferation (Lei et al. 2009, Kaloglu \& Onarlioglu 2010, Macdonald et al. 2011, Afshar et al. 2012) and the tissue remodelling process also take place in the uterus (Fazleabas \& Strakova 2002, Rosario et al. 2003, Kaloglu \& Onarlioglu 2010), and can be influenced by PARP1 (Pagano et al. 2007, Kobayashi 2011). In endometrial carcinoma, PARP1 can regulate the progesterone receptor (PR; Ghabreau et al. 2004), suggesting the involvement of PARP1 in ovarian steroid signalling. Conversely, the activity of PARP can be under oestradiol regulation (Suzuki et al. 1990), suggesting cross-talk between PARP1 and ovarian steroid signalling. These findings raise the possibility of association of PARP1 with uterine receptivity for successful embryo implantation. Therefore, in this study, we explored the role of PARP1 in the uterus during embryo implantation and also examined its regulation by ovarian steroids.

\section{Materials and methods Reagents}

Anti-PARP1 (sc25780), anti-STAT3 (sc483), anti-caspase-3 (sc7148), caspase-3 inhibitor (sc300325) and inhibitor of PARP1 (EB-47, sc222125) were obtained from Santa Cruz Biotechnology Inc., Santa Cruz, CA, USA and have already been characterised (Jagtap et al. 2004, Watzlawik et al. 2010). Cleaved PARP1 (Asp214, 7C9), mouse mAb (Mouse Specific, 9548) and p-STAT3 (Serine 727) (9134S) were from Cell Signaling Technology Inc., Danvers, MA, USA. The secondary antibody conjugated with HRP (goat anti-rabbit IgG, 621140380011730) was from Merck-Millipore, Molsheim, France. The steroids hormones (progesterone and oestrogen), phosphatase inhibitor cocktail (P5726), protease inhibitor (S8830), anti- $\beta$-actin (A3854), Trizol reagent (T9424) and anti-histone H-3 (H9289) were from SigmaAldrich, Inc. The Immobilon-P PVDF membrane $(0.2 \mu \mathrm{m})$ and ECL reagent (WBKLS0500) kits were from Merck-Millipore, MA, USA and GE Healthcare Life Sciences, Pittsburgh,PA, USA respectively. Superscript III first-strand cDNA synthesis supermix (18080-400) and Platinum blue PCR supermix (12580-015) were from Life Technology, Carlsbad, CA, US. Light cycler 480 SYBR green 1 master (04707516001, lot 14555300) was purchased from Roche Applied Science, Indianapolis, IN, USA. PCR primers of PARP1 and $\beta$-actin were synthesised by Integrated DNA Technology (IDT), Leuven, Belgium. The caspase-3 activity assay kit (K106-100) was supplied by BioVision Inc., Milpitas, CA, USA. Protein standard (SM0671) was purchased from Fermentas, St. Leon-Rot, Germany.

\section{Experimental animals}

The entire study was conducted on Mus musculus (Swiss strain, albino) as used earlier (Jha et al. 2006, Maurya et al. 2013). Animals (out-bred) were 3 months old and they were housed in polycarbonate cages under a $12 \mathrm{~h}$ light: $12 \mathrm{~h}$ darkness regimen with a controlled temperature of $27 \pm 1{ }^{\circ} \mathrm{C}$. All the mice had free access to food and water. The animal experimental protocol was in accordance with the guidelines of the CSIRCDRI Animal Ethical Committee, Lucknow, UP, India.

\section{Embryo implantation mouse model}

Pregnancy was established in mice by caging sexually mature (3-4 months old) and virgin females with males (3-4 months old) of proven fertility. Pregnancy was confirmed by the presence of a whitish vaginal plug the following day, designated day 1 of pregnancy (Pakrasi \& Jain 2008). Female mice were killed at different days of embryo implantation i.e. pre-implantation (day $4(1000 \mathrm{~h})$ ), late pre-implantation (day 4 (1600 h)), peri-implantation (day 5 (0500 h)) and postimplantation (day $5(1000 \mathrm{~h})$ ) according to a previous study (Maurya et al. 2013). During peri- and post-implantation stages, implantation sites were rendered visible via tail-vein injection of $100 \mu \mathrm{l}$ Evans blue dye (1\%) suspension in saline. Extra-vascular Evans blue dye accumulation in the areas of blastocyst-induced increased capillary permeability reveals sites of implantation as discrete blue bands (Psychoyos 1986). The uterine tissue was obtained by the cervical dislocation method. The implantation sites were demarcated by discrete blue bands (Evans blue stain) and the spaces between the blue bands (without/faint colour) were termed inter-implantation or non-implantation sites (Kondoh et al. 2009). The Evans blue coloured implantation sites and the non-/less coloured non/inter-implantation regions were separated and processed for protein extraction.

\section{Experimental decidualisation induction in pseudopregnant mice}

Experimental decidualisation was induced in pseudopregnant female mice. The pseudopregnancy was obtained by natural mating with vasectomised male mice. The male mice were vasectomised as described previously (Ittner \& Gotz 2007) and allowed to rest for a week to recover from the injury. Thereafter, sexually mature female mice were housed with these vasectomised males. Females displaying a whitish vaginal plug on the following day were considered pseudopregnant. The presence of a vaginal plug confirmed successful mating and the day was designated day 1 of pregnancy. Experimental decidualisation was stimulated in the pseudopregnant female mice at day $3(1600 \mathrm{~h})$ by the introduction of an intra-uterine lumen infusion of $10 \mu \mathrm{l}$ corn oil into one uterine horn lumen. The contralateral non-infused horn served as a control nondecidualised horn. The decidualised and non-decidualised uterine horns were collected $72 \mathrm{~h}$ after corn oil infusion (Nakamura et al. 2006).

\section{Delayed implantation mice model}

Delayed implantation was induced in the pregnant female mice after confirmation of their successful mating by the observation of a vaginal plug. The ovaries of the pregnant female mice were excised by bilateral ovariectomy on day 3 at $1600 \mathrm{~h}$. This process was carried out under ketamine $(30 \mathrm{mg} / \mathrm{kg}$ body weight) and xylazine ( $4 \mathrm{mg} / \mathrm{kg}$ body weight) anaesthesia, under aseptic conditions. The ovariectomised female mice were divided randomly into two groups comprising a minimum of five animals each. Group 1 animals received progesterone ( $1 \mathrm{mg} / 20 \mathrm{~g}$ body weight) at $1700 \mathrm{~h}$ from day 3 to day 7 of the 
pregnancy, while group 2 animals received progesterone from day 3 to day 7 along with oestradiol on day 7 ( $25 \mathrm{ng} / 20 \mathrm{~g}$ body weight). These steroids were administered subcutaneously. Progesterone (4-pregnen-3,20-dione) was dissolved in corn oil at a concentration of $20 \mathrm{mg} / \mathrm{ml}$ and oestrogen (1,3,5(10)oestratriene-3,17- $\beta$-diol) ( $\beta$-oestradiol) was dissolved in corn oil at a concentration of $500 \mathrm{ng} / \mathrm{ml}$. The hormone treated mice were killed at $1700 \mathrm{~h}$ on day 8 of pregnancy by cervical dislocation. The uterine horn was flushed gently to obtain embryos and the collected embryos from various stages of delayed pregnancy were verified as reported earlier (Maurya et al. 2013). Non-implanted or hatched dormant blastocysts were seen in the progesterone-treated animal group, whereas in the progesterone $+17 \beta$-oestradiol-treated group implanted blastocysts were visible by their trophoblast cell protrusions sites (Paria et al. 1993, Lee et al. 2011, Maurya et al. 2013). The uterine adherent fat was cleared by washing thoroughly in PBS and processed for protein extraction.

\section{Protein extract (cytosolic and nuclear) preparation from the uterus}

To isolate the uterine cytosolic protein fraction, excised uterus ( 100 mg) was minced thoroughly in $200 \mu \mathrm{l}$ buffer containing $100 \mathrm{mM} \mathrm{KCl}, 3 \mathrm{mM} \mathrm{NaCl}, 3.5 \mathrm{mM} \mathrm{MgCl}$, $10 \mathrm{mM}$ Pipes, $1.5 \mathrm{mM}$ EGTA, phosphatase and protease inhibitor $(\mathrm{pH} 7.4)$ in accordance with the previously described method (Maurya et al. 2013). This was followed by homogenisation of uterine tissue and centrifugation at $4{ }^{\circ} \mathrm{C}, 200 \mathrm{~g}$ to separate unbroken cells. Then the $200 \mathrm{~g}$ supernatant was centrifuged at $1475 \mathrm{~g}$ to remove nuclei. The post-nuclear supernatant was further centrifuged at $12000 \mathrm{~g}\left(10 \mathrm{~min}\right.$ at $\left.4{ }^{\circ} \mathrm{C}\right)$; the resultant supernatant, designated the whole uterine tissue crude cytosolic protein extract, was stored at $-80^{\circ} \mathrm{C}$ until use.

The nuclear pellet obtained by centrifugation at $1475 \mathrm{~g}$ was reconstituted in hypotonic buffer (20 mM HEPES, pH 7.9; $1 \mathrm{mM}$ EDTA, $10 \mathrm{mM} \mathrm{KCl}, 1 \mathrm{mM}$ EDTA, $1 \mathrm{mM} \mathrm{MgCl} 2,1 \mathrm{mM}$ dithiothreitol (DTT) and $400 \mathrm{mM} \mathrm{NaCl}, \mathrm{pH}$ 7.8) containing protease and phosphatase inhibitor cocktail and incubated in a rocking mode at $4{ }^{\circ} \mathrm{C}$ for $30 \mathrm{~min}$. Thereafter, the mixture was centrifuged at $20,800 \mathrm{~g}$ at $4{ }^{\circ} \mathrm{C}$ for $30 \mathrm{~min}$ (DavoodiSemiromi et al. 2004). The supernatant (nuclear extract) was collected and stored at $-80^{\circ} \mathrm{C}$. Protein concentration was determined using the Bio-Rad DC protein assay kit method and the protein concentration was adjusted to $20 \mu \mathrm{g}$.

\section{SDS-PAGE and western blotting}

Uterine cytosolic and nuclear protein fractions were denatured in Laemmli buffer (Laemmli 1970, Laemmli et al. 1970) containing $\beta$-mercaptoethanol followed by heating at $95{ }^{\circ} \mathrm{C}$ for $5 \mathrm{~min}$. A total of $20 \mu \mathrm{g}$ protein was loaded into each well and resolved on $10 \%$ SDS-PAGE at $100 \mathrm{~V}$ using the TetraProtean Cell vertical electrophoretic system (Bio-Rad). Then the proteins were electro-blotted onto PVDF membrane using transfer buffer containing 20\% v/v methanol, $25 \mathrm{mM}$ Tris, $\mathrm{pH}$ 8.2, $190 \mathrm{mM}$ glycine at $50 \mathrm{~mA}$ per gel for $12 \mathrm{~h}$ (Towbin et al. 1992).

\section{Immunoblotting}

The blotted membranes were first incubated with 5\% non-fat milk blocker in PBS containing 0.1\% Tween-20 (PBS-T) for $2 \mathrm{~h}$. Then they were incubated with the respective primary antibody, i.e. for PARP1 (1:1000 dilution), caspase-3 (1:500 dilution), STAT3 (1:200 dilution), p-STAT3 (1:500 dilution), histone $\mathrm{H}-3$ (1:3000 dilution) and $\beta$-actin (1:3000 dilution) for $2 \mathrm{~h}$ at room temperature in the presence of $2 \%$ milk blocker. Finally, membranes were probed with secondary antibody (anti-rabbit $\operatorname{lgG}$ ) conjugated with HRP in PBS-T containing $2 \%$ milk blocker. PBS-T was used throughout the procedure and each step was followed by three washes with PBS-T. The dilution of the secondary antibody (anti-rabbit IgG HRP) was 1:3000 for PARP1 and $\beta$-actin antibodies. The blots of histone $\mathrm{H}-3$ were incubated with anti-rabbit IgG HRP at 1:4000 dilution. The presence of antibody-protein complexes on the blot was detected with the $\mathrm{ECL} / \mathrm{ECL}$ plus kit. Immunoblots were imaged through the chemiluminescence documentation system (ImageQuant LAS 4000, GE Healthcare Life Science). Antibody specific for $\beta$-actin was used as an internal loading control for proteins. The protein bands were scanned densitometrically using the TotalLab Quant software (Nonlinear Dynamics, Newcastle upon Tyne, UK). Results are expressed as a ratio (protein of interest: $\beta$-actin) to correct for the loading of each sample.

\section{PARP1 in vivo assay}

Each male mouse (Swiss Strain, 3 months old) was co-habited with two females. Day 1 of pregnancy was the day when a whitish vaginal plug was seen in the morning after mating. Animals were anaesthetised with ketamine $(30 \mathrm{mg} / \mathrm{kg})$ and xylazine $(4 \mathrm{mg} / \mathrm{kg})$ at day $4(1000 \mathrm{~h})$ of pregnancy. The anaesthetised animal was placed in a dorso-ventral position, a cut of $\sim 1 \mathrm{~cm}$ was made in the dorsal mid-lumbar area to visualise the uterus, and an inhibitor of PARP1 (EB-47, $2 \mu \mathrm{M}$ concentration and $3 \mu$ volume; Jagtap et al. 2004) was infused via the intra-uterine route into the left horn of the uterus and the corresponding vehicle (sterile distilled water, $3 \mu$ l volume) was infused into the right horn. On day 5 (1000 h) of pregnancy, Evans blue dye was injected into the mice via the tail vein $1 \mathrm{~h}$ before they were killed. The animals were killed by cervical dislocation and the numbers of implanted and non-implanted sites in PARP1-inhibited as well as sham-treated horns were observed. Thereafter, the number and morphology of blastocysts were recorded.

\section{Caspase-3 in vivo assay}

Intra-luminal delivery of caspase-3 inhibitor was performed on day $4(1000 \mathrm{~h})$ and its effect on embryo implantation (sites of embryo implantation) was evaluated by administering Evans blue dye $(0.01 \%$ in PBS). Pregnant female mice were anaesthetised with ketamine $(30 \mathrm{mg} / \mathrm{kg})$ and xylazine $(4 \mathrm{mg} / \mathrm{kg}$ ) and placed in a dorso-ventral position. Using a surgical blade, an incision (1-2 cm) was made near the dorsal mid-lumbar area just below the kidney region. The uterine horn was held gently with forceps and caspase-3 inhibitor $(5 \mu \mathrm{g} / 3 \mu \mathrm{l})$ was delivered into the left uterine horn while the corresponding 
vehicle ( $3 \mu \mathrm{l}$ volume) was infused into the right horn. Both the dermis and skin were stitched back with sutures. On day 5 $(1000 \mathrm{~h})$ of pregnancy, Evans blue dye $(1 \%)$ in PBS was given via the tail vein, the mice were killed by cervical dislocation, and implantation sites and implanted embryos were counted.

\section{Caspase- 3 activity assay}

Caspase-3 activity was assayed in the uterine samples by means of a caspase-3/CPP32 colorimetric assay kit (K106-100) as per the manufacturer's instructions. Briefly, a total of $50 \mu \mathrm{g}$ protein from the uterus (cytosolic + nuclear) fraction was added to $50 \mu$ of $2 \times$ reaction buffer (containing $10 \mathrm{mM} \mathrm{DTT}$ ), followed by $5 \mu \mathrm{l}$ of $4 \mathrm{mM}$ DEVD-pNA substrate. The suspension was incubated at $37^{\circ} \mathrm{C}$ for $1-2 \mathrm{~h}$ and absorbance was recorded at $405 \mathrm{~nm}$ with a micro plate reader (ELISA plate reader, BioTek, Winooski, VT, USA).

\section{PCR}

All the experiments were performed under RNase-free conditions. Total RNA was extracted from uterine tissue using Trizol reagent according to the manufacturer's protocol. The concentration of RNA was measured by Nanodrop (Thermo Fisher Scientific, Wilmington, DE, USA). Uterine tissue cDNA was synthesised using $1 \mu \mathrm{g}$ RNA and the SuperScript III cDNA synthesis kit as per the manufacturer's instructions. Each semiquantitative PCR had the following components: $1 \mu \mathrm{l}$ of RT product, $23 \mu \mathrm{l}$ of Platinum blue PCR Super Mix and 20 pmol of forward and reverse primers. PCR was performed on a C1000 thermal cycler (Bio-Rad Laboratories) for 38 cycles $\left(95^{\circ} \mathrm{C}\right.$ for $1 \mathrm{~min} ; 53{ }^{\circ} \mathrm{C}$ for $1 \mathrm{~min}, 72{ }^{\circ} \mathrm{C}$ for $1 \mathrm{~min}$ and a final extension of $10 \mathrm{~min}$ at $72{ }^{\circ} \mathrm{C}$ ) after an initial $5 \mathrm{~min}$ incubation at $95^{\circ} \mathrm{C}$. The primer sequences used to detect the Parp1 gene were $5^{\prime}$-CACCCTCCAAGAAGAGCAAG-3' (sense) and 5'-CTCTCCTTGTCGGACTCCAG-3' (anti-sense). The expression of $\beta$-actin (primers $5^{\prime}$-TACTCCTGCTTGGTGA TCCAC- $3^{\prime}$ (sense) and $5^{\prime}$-ATCTGGCACCACACCTTCTAC-3' (anti-sense)) was used as endogenous control (Spina-Purrello et al. 2010). Amplified products were resolved in 1.5\% agarose gel and imaged using the Gel documentation system (Bio-Rad). Band intensity was analysed using Total Lab Quant 1D software version 5.0 (Nonlinear Dynamics) and mean value, along with s.D., error and $t$-test, were calculated.

\section{Real-time PCR}

Quantitative RT-PCR was carried out on a LightCycler 480 instrument II (Roche Diagnostics). Uterine cDNA was diluted with nuclease-free water. One microlitre of cDNA was mixed with $8.0 \mu \mathrm{l}$ of Light Cycler 480 SYBR green master mix (Roche Diagnostics) and $1.0 \mu \mathrm{l}$ of primer (20 pmol forward/ reverse). The final volume was adjusted to $15 \mu \mathrm{l}$ with nuclease-free water. The primers used for Parp1 were 5'-GGACGAAGAGGCAGTAAAGAAG-3' (sense) and 5'-CTCGCTGAGGTAAGAGTAGGC-3' (antisense) (NC_000067.6). The primers used for the reference gene ( $\beta$-actin) were $5^{\prime}$-AGCCATGTACGTAGCCATCC-3' (sense) and $5^{\prime}$-GCTGTGGTGGTGAAGCTGTA-3' (antisense) (NC_000071.6).
These primers were intron-spanning and were designed by means of Primer3 (http://bioinfo.ut.ee/primer3-0.4.0/) to amplify a $<200$ bp product. Thermal cycling was carried out as follows. The first segment of the amplification cycle consisted of denaturation at $95^{\circ} \mathrm{C}$ for $10 \mathrm{~min}$; the second segment consisted of a four-step denaturation $\left(15 \mathrm{~s}\right.$ at $\left.95^{\circ} \mathrm{C}\right)$, primer annealing $\left(30 \mathrm{~s}\right.$ at $\left.58{ }^{\circ} \mathrm{C}\right)$ and extension $\left(30 \mathrm{~s}\right.$ at $\left.72{ }^{\circ} \mathrm{C}\right)$ for 40 cycles. The third segment consisted of a melting curve programme $\left(95^{\circ} \mathrm{C}\right.$ for $5 \mathrm{~s}, 58^{\circ} \mathrm{C}$ for $\left.15 \mathrm{~s}\right)$. The final segment consisted of cooling to $40^{\circ} \mathrm{C}$. The threshold cycle $\left(C_{\mathrm{T}}\right)$ was used to represent the relative mRNA amounts. All samples were run and analysed in triplicate using the $2^{-\Delta \Delta C_{\mathrm{T}}}$ method (Livak \& Schmittgen 2001).

\section{Statistical analysis}

All the experiments were repeated a minimum of three times using separate animals for each replicate $(n=5)$. The protein band intensity was analysed by Totallab Quant gel analysis software version 5.01 (Nonlinear Dynamics). Protein band intensities were averaged and the S.E.M. was calculated. All values were expressed as the mean \pm S.E.M. of at least three independent experiments. Histograms were plotted of protein band intensity for various stages/groups using Microsoft Excel 2007. The band intensities obtained from the immunoblots were compared within the phases of embryo implantation using Student's paired $t$-test. The data were subjected to one-way ANOVA using Microsoft Excel 2007. The statistical significance level was considered to be 0.05 for all tests analysed. $\beta$-Actin antibody was used to normalise the PARP1, caspase-3 and STAT3 values. Histone $\mathrm{H}-3$ was used as a nuclear compartment marker.

\section{Results \\ Expression of PARP1 is upregulated in the uterus during embryo implantation}

Expression of native PARP1 protein in uterine protein extracts was studied by immunoblotting to examine its relation with endometrial receptivity/implantation. The invasive period in rodents is day 4-10 of pregnancy, when the endometrial stromal cells undergo extensive remodelling in response to blastocyst implantation; the loss of the luminal epithelium is evident at this stage (Enders 2000, Kennedy et al. 2007). Therefore, we analysed PARP1 expression levels at day 4 (1000 h), day 4 (1600 h), day 5 (0500 h) and day 5 (1000 h) of embryo implantation. We separated implantation and nonimplantation sites at the peri-implantation to postimplantation stages and analysed the expression levels of the native and cleaved forms of PARP1 in the cytosol as well as in the nuclear compartment (Figs 1 and 2).

The native form of PARP1 $(\sim 116 \mathrm{kDa})$ was present at a basal level in the cytosol at the pre-implantation (day 4 $(1000 \mathrm{~h})$ ) and late pre-implantation stages (day 4 $(1600 \mathrm{~h})$ ) (Fig. 1A and B). The expression level of native PARP1 was higher at implantation sites at the periimplantation stage (day $5(0500 \mathrm{~h}))(P<0.05)$ than at the 


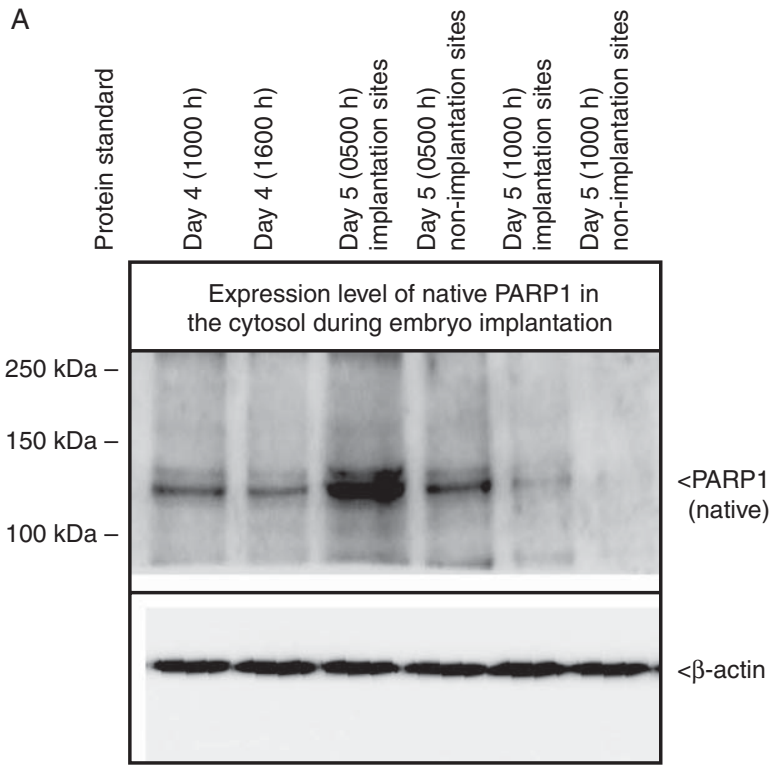

C
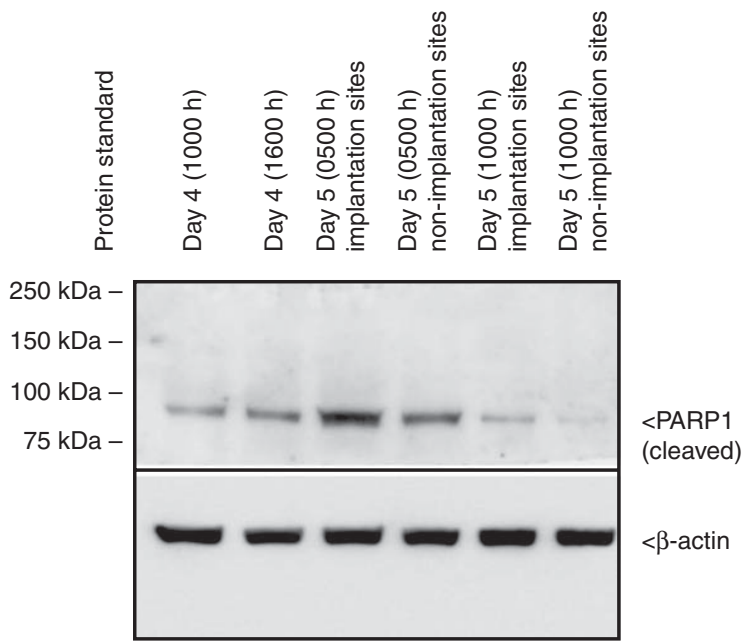

B

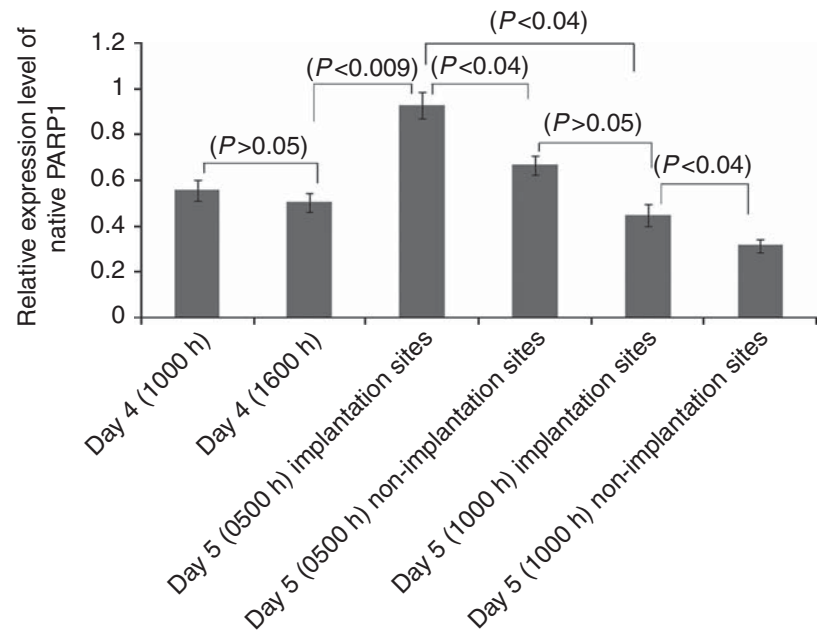

Stages of embryo implantation

$\mathrm{D}$

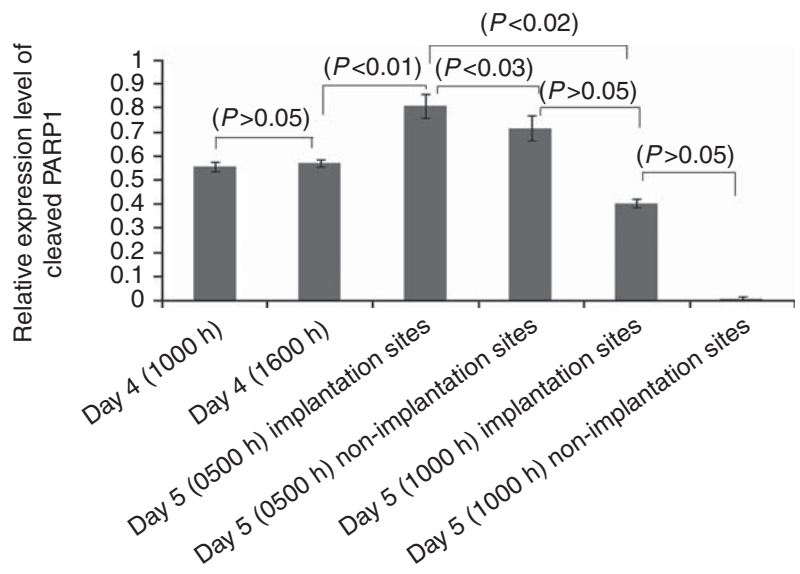

Stages of embryo implantation

Figure 1 Determination of expression level of PARP1 in the uterine cytosol. Using immunoblotting, the expression level of PARP1 (native and cleaved form) was evaluated in the uterine cytosolic compartment of mice during different stages of embryo implantation (A, B, C and D). The expression of cytosolic PARP1 was analysed by densitometry (B and D). $\beta$-actin was used as a loading control for the immunoblot of PARP1 in the cytosolic protein fraction.

late-pre-implantation stage (Fig. 1A and B). However, it showed a no change at non-implantation sites during the peri-implantation period (day $5(0500 \mathrm{~h}))(P<0.04)$. At the following stage (day $5(1000 \mathrm{~h})$ ), there was no change in the expression level of native PARP1 at implantation sites (Fig. 1A and B). We observed a fall in the expression level of native PARP1 at non-implantation sites at postimplantation stage (day $5(1000 \mathrm{~h}))(P<0.04)$ compared with implantation sites (Fig. $1 \mathrm{~A}$ and $\mathrm{B}$ ). Similar results were observed for the cytosolic cleaved form of PARP1 $(\sim 89 \mathrm{kDa})$, which was noted to be higher during late pre- to peri-implantation stages, and declined at postimplantation stage $(P<0.02)$ (Fig. 1C and D).
We also studied the native and cleaved forms of PARP1 in the nuclear fraction. We observed an augmentation in the expression level of the native form during day $4(1600 \mathrm{~h})$ and day $5(0500 \mathrm{~h})$ in comparison with day $4(1000 \mathrm{~h})(P<0.003$ and $P<0.0001$ respectively) (Fig. $2 \mathrm{~A}$ and $\mathrm{B}$ ), and this level remained high at the non-implantation sites at day $5(0500 \mathrm{~h})$. At the advanced stage (day $5(1000 \mathrm{~h})$ ), the expression level of native PARP1 was downregulated $(P<0.005)$ (Fig. 2A and $\mathrm{B})$, and no difference was observed at the nonimplantation sites at day $5(1000 \mathrm{~h})$. Expression of the cleaved form of PARP1 ( $\sim 89 \mathrm{kDa})$ followed a similar pattern (Fig. 2C and D). 
A
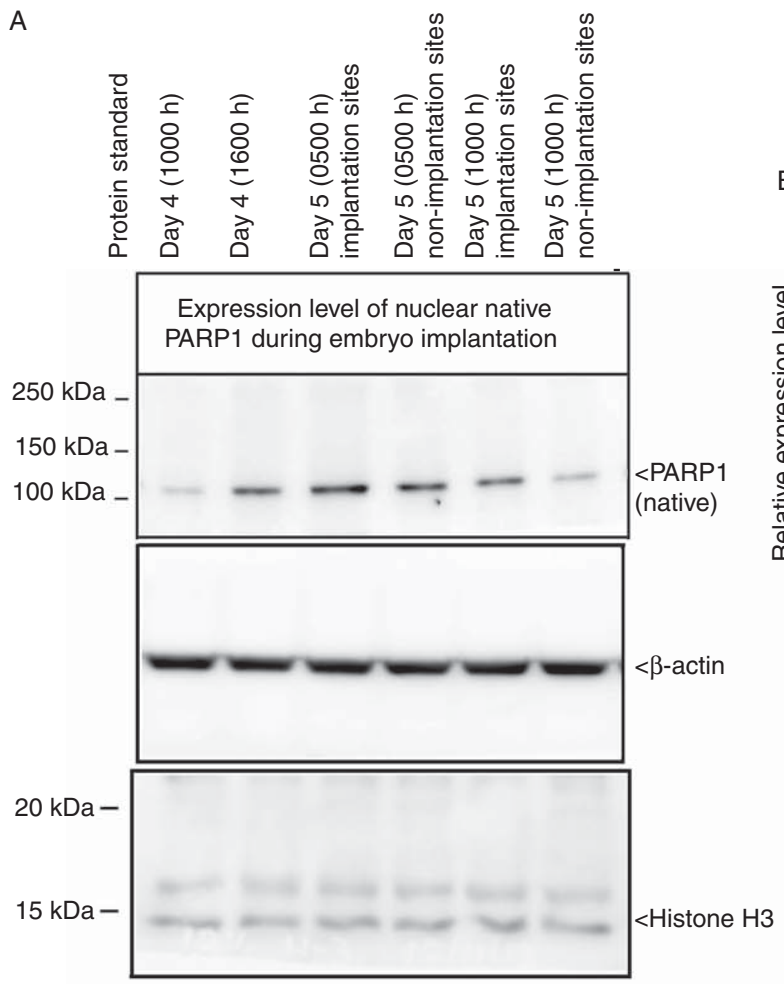

C

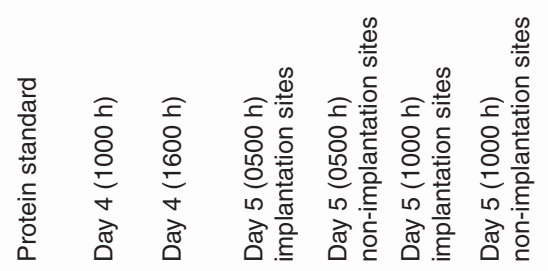

$<$ PARP1

(cleaved)

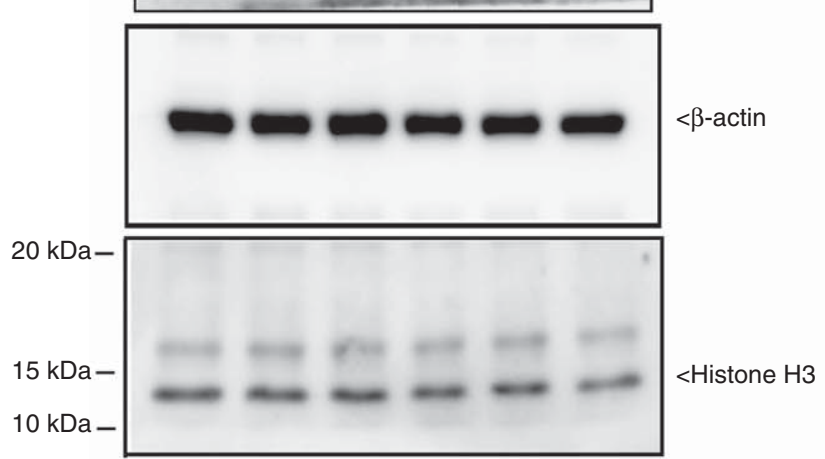

B

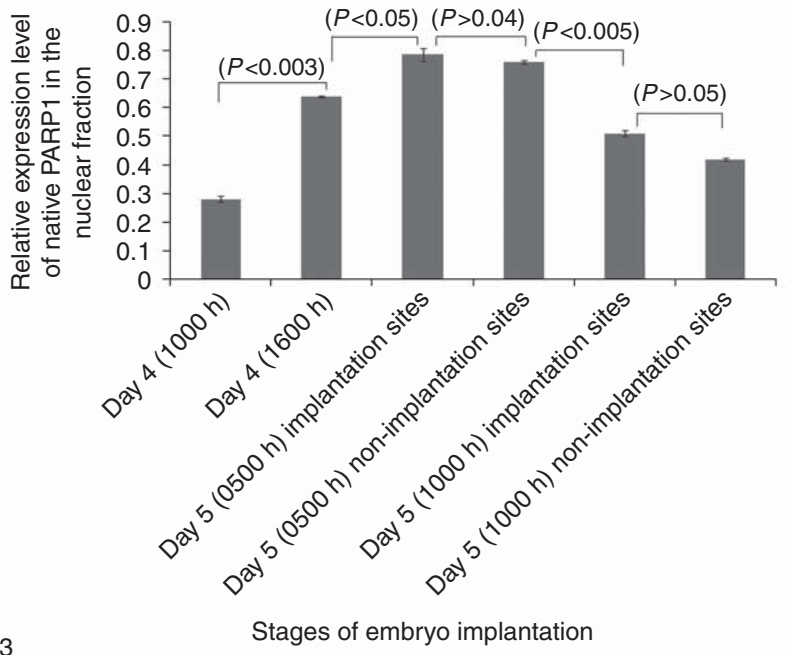

D

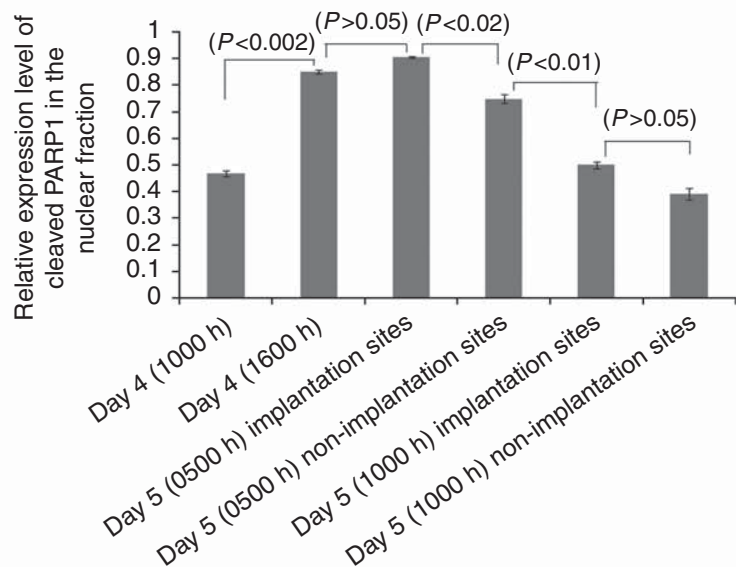

Stages of embryo implantation

Figure 2 Expression of the native and cleaved forms of PARP1 in the nuclear compartment of the uterus. The native and cleaved forms of PARP1 in the nuclear protein fraction isolated from the uterus during embryo implantation were analysed simultaneously (A, B, C and D). $\beta$-actin was used as a loading control for the immunoblot of PARP1 in the nuclear protein fraction. Histone H3 was used as a nuclear compartment marker. 
To investigate the transcript level of Parp1, we carried out PCR using cDNA (synthesised from isolated mRNA) from various stages of implantation. Our study revealed a low/basal level of Parp1 transcript at day 4 (1000 h), and an elevated level at late pre-implantation stage (day 4 $(1600 \mathrm{~h}))(P<0.01)$ (Fig. 3A and B). The expression level of Parp1 transcript was further increased at day 5 $(0500 \mathrm{~h})$ (implantation and non-implantation sites) $(P<0.009)$, but at the advanced stage, post-implantation (day $5(1000 \mathrm{~h})$ ), this expression was downregulated $(P<0.01)$ (Fig. 3A and B). Similar results were exhibited by quantitative real-time PCR analysis. Using qRT-PCR, Parp1 transcripts were detected at all of the stages of implantation that were studied. We observed that the expression level of Parp1 was maximum (twofold) at implantation sites at day $5(0500 \mathrm{~h})$, whereas it was least at day 4 (1000 h Fig. 3C). The non-implantation sites showed reduced expression of Parp1 compared with implantation sites at day 5 (0500 and 1000 h Fig. 3C). The mRNA expression levels of Parp1 correlated well with the protein expression data.

\section{Elevated expression of PARP1 and caspase-3 in the decidualised uterus}

Decidualisation involves stromal cell proliferation and differentiation into morphologically distinct decidual cells as a remodelling process, followed by embryo implantation (Fazleabas \& Strakova 2002). In fact, programmed cell death also occurs in the uterus (Pampfer \& Donnay 1999), and we speculated that PARP1 might be involved in this process. Therefore, we next investigated the relation of PARP1 with decidualisation in the uterine cytosol using western blotting. The native form of PARP1 $(\sim 116 \mathrm{kDa})$ was detected in protein samples of uterine tissue of decidualised and non-decidualised groups (Fig. 4A). Decidualised uterus showed increased expression of native PARP1 in comparison with the non-decidualised group $(P<0.03)$ (Fig. 4A and B). Later, we examined the cleaved form of PARP1 in the decidualised uterus and its expression level was noted to be similar to that of native PARP1 (Fig. 4C and D).

PARP1 is a known substrate for caspase-3 (Brustmann 2007); therefore, to confirm the cleavage of PARP1 in the decidualised uterus, we investigated the action of caspase-3. We analysed the expression levels of pro-caspase- 3 and caspase- 3 (p17/active caspase-3) in the decidualised uterus. Our results showed a nonsignificant difference $(P>0.05)$ in pro-caspase-3 expression between the decidualised and non-decidualised uterus groups, whereas active caspase- 3 was found to be significantly elevated in the decidualised group in comparison with the non-decidualised group $(P<0.0001)$ (Fig. 4E and F).

\section{Effect of PARP1 inhibition on embryo implantation}

To confirm the functional role of PARP1 during embryo implantation, we administered an inhibitor of PARP1 during the pre-implantation period and observed its effect on the post-implantation stage. Intra-luminal delivery of PARP1 inhibitor at the pre-implantation stage showed a reduction in embryo implantation sites $(P<0.01)$ and blastocyst numbers $(P<0.01)$ (Fig. 5A, B, $\mathrm{C}$ and $\mathrm{D})$. To examine the signalling of PARP1 for embryo implantation in the receptive uterus, we determined the expression level of STAT3 in the PARP1-inhibited group. STAT3 is known to be an essential signalling molecule for embryo implantation/uterine receptivity (Nakamura et al. 2006). We observed a compromised expression level of STAT3 at the implantation sites of the PARP1inhibited group compared with the sham/vehicle-treated group $(P<0.04)$ at day $5(1000 \mathrm{~h})$ (Fig. $5 \mathrm{E}$ and $\mathrm{F})$. A similar pattern was noticed at the non-implantation sites $(P<0.008)$ (Fig. 5E and F). Further, active (phosphorylated) STAT3 demonstrated downregulation at the nonimplantation sites of the PARP1-inhibited uterus group compared with the implantation sites of the sham and PARP1 inhibitor-treated groups $(P<0.05, P<0.009)$ (Fig. 5G and $\mathrm{H}$ ). No significant difference was observed between the implantation sites of the PARP1-inhibited and sham-treated groups (Fig. 5G and H). The PARP1 inhibition effect was also seen in the non-implantation sites containing STAT3, where the expression level of STAT3 was decreased (Fig. 5E and F). The activity of STAT3 was maintained in the implantation sites and decreased in the non-implantation sites at the day 5 (1000 h) stage (Fig. 5G and H).

\section{Consequence of inhibition of caspase-3 activity on day $4(1000 \mathrm{~h})$ embryo implantation}

In mice and hamsters, uterine cells undergo apoptosis during days 5-8 of pregnancy (Zhang \& Paria 2006). Therefore, we determined the activity of caspase-3 during the stages of embryo implantation. The activity of caspase-3 was moderate during the pre-implantation stage, and augmented at late-pre-implantation stage $(P<0.005)$ (Fig. 6A). The activity was further increased at implantation sites at day $5(0500 \mathrm{~h})$, but at the following stage, day $5(1000 \mathrm{~h})$, demonstrated reduced activity. Non-implantation sites at day $5(0500 \mathrm{~h})$ showed decreased activity of caspase- 3 compared with implantation sites (Fig. 6A).

To confirm the action of caspase- 3 at day 5 (1000 h), its activity was analysed in the post-caspase-3-inhibited uterus. As expected, the activity of caspase- 3 was significantly reduced in the treated samples compared with sham-treated/control samples at both implantation $(P<0.005)$ and non-implantation $(P<0.05)$ sites at day 5 (1000 h) (Fig. 6B). 
A
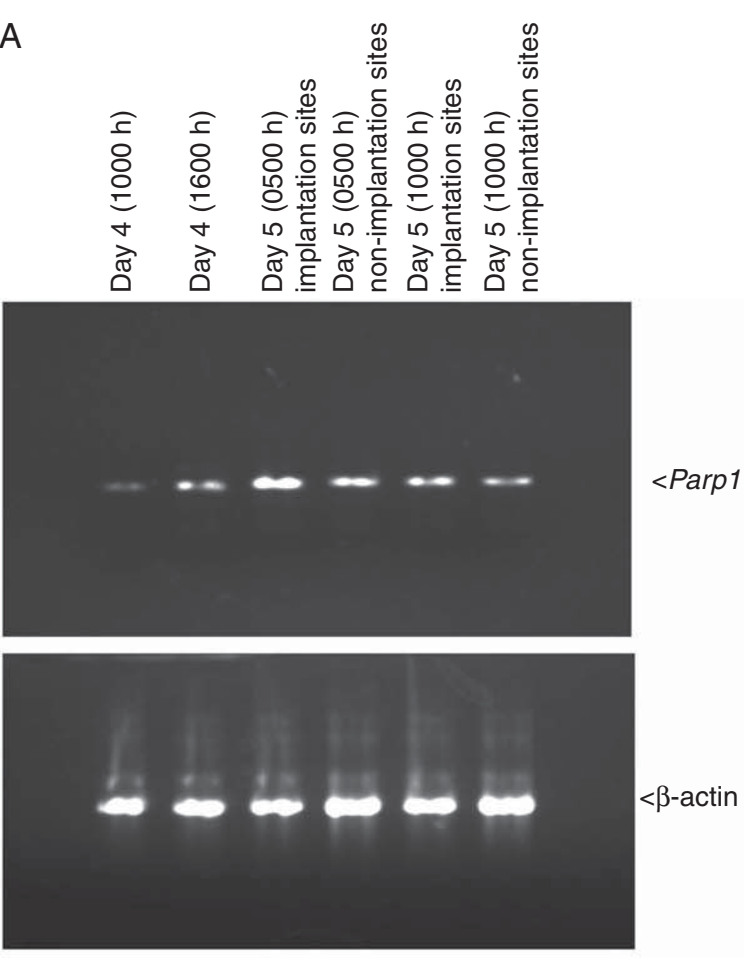

C
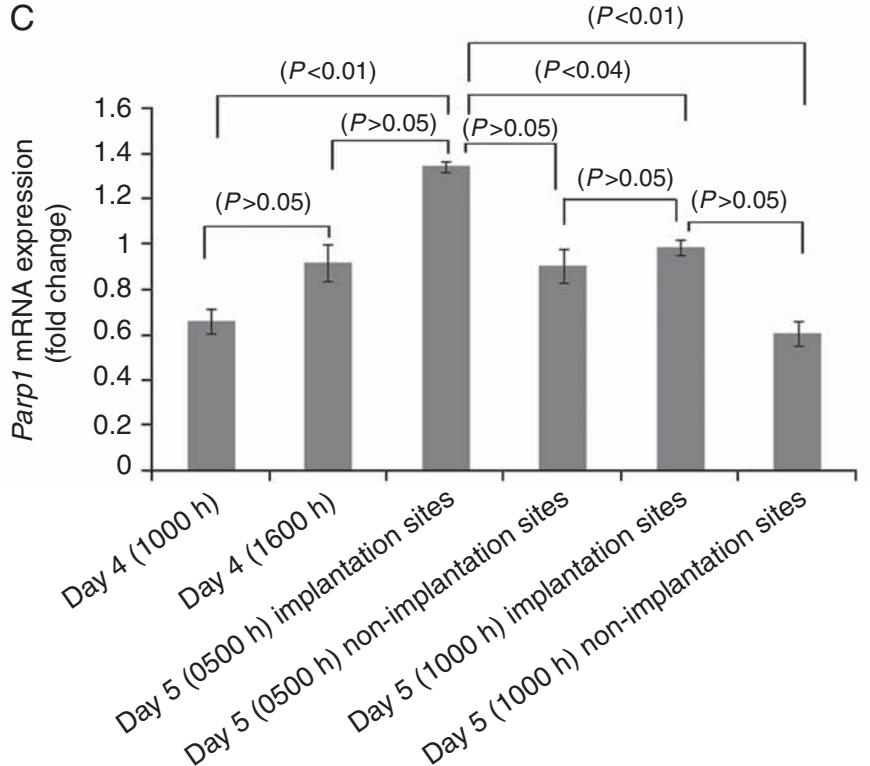

B

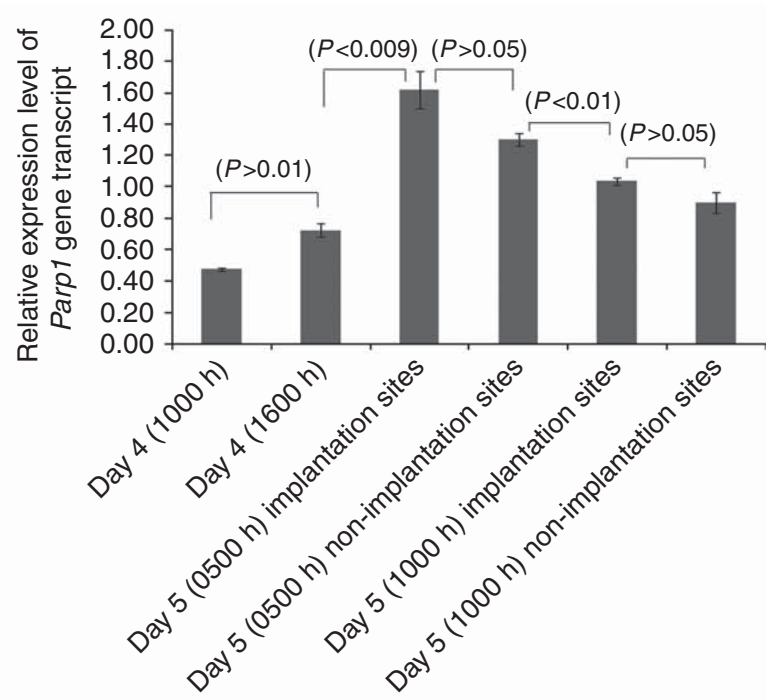

Stages of embryo implantation

Stages of embryo implantation

Figure 3 Analysis of the gene transcript level of PARP1 during embryo implantation. PCR and real-time PCR were used to analyse the expression levels of the Parp1 gene transcript in the uterus at different stages of embryo implantation (A, B, C). $\beta$-actin was used as a reference gene.

As shown in Fig. 6C and D, administration of caspase3 inhibitor at pre-implantation stages reduced the number of sites of embryo implantation compared with the sham-treated group $(P<0.03$; Fig. $6 \mathrm{C}$ and $\mathrm{D})$. The number of embryo implantation sites (blue bands) was recorded visually; the inhibitory effect of caspase-3 activity blocker was nearly 70\% (Fig. 6D).
PARP1 is a substrate of caspase-3; therefore, to confirm the action of caspase-3 on PARP1, we measured the expression levels of the cleaved and native forms of PARP1 protein in the caspase-3-inhibited uterine protein samples using western blotting. The expression level of the cleaved form of PARP1 was seen to be decreased in caspase-3-inhibited samples (Fig. 6E and F) from 

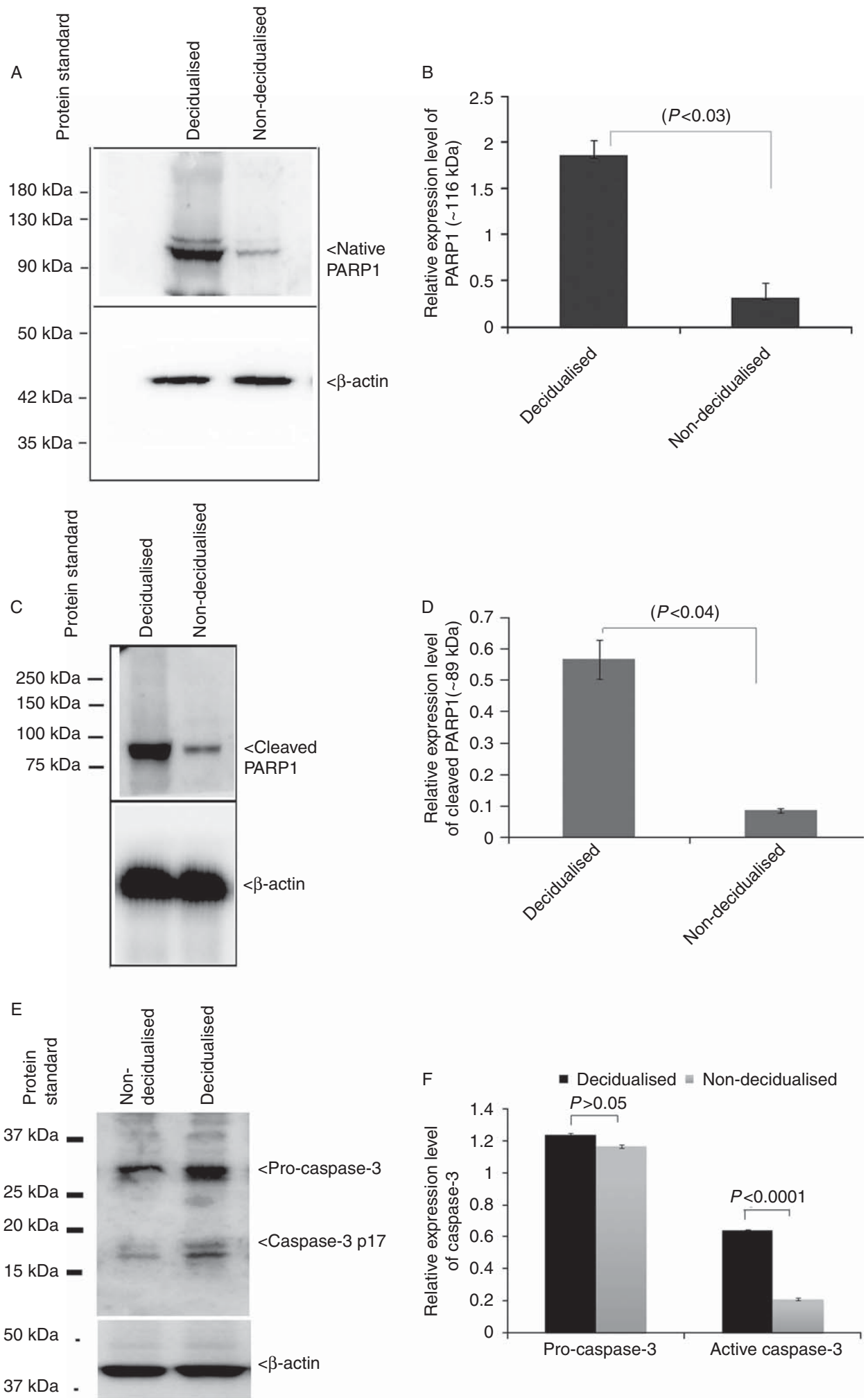

Figure 4 Association of the native and cleaved forms of PARP1 with decidualisation. The expression level of the native form of PARP1 in the crude cytosolic fraction from the uterus was studied using immunoblotting ( $A$ and B). The cleaved form of PARP1 was also investigated in the decidualised and non-decidualised uterus (C and D). The expression levels of pro- and active caspase- 3 were also analysed in the decidualised and nondecidualised uterus (E and F). The values of PARP1 and caspase-3 expression in the cytosolic compartment were normalised with the $\beta$-actin of the corresponding replicate. 
A

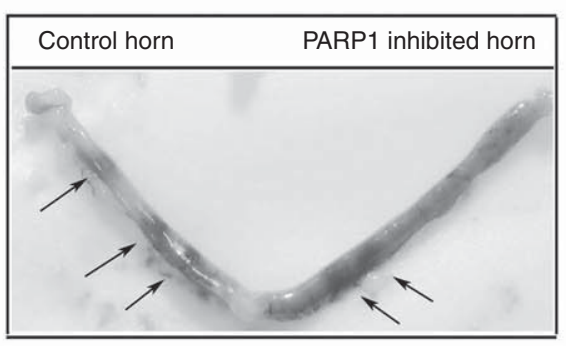

C
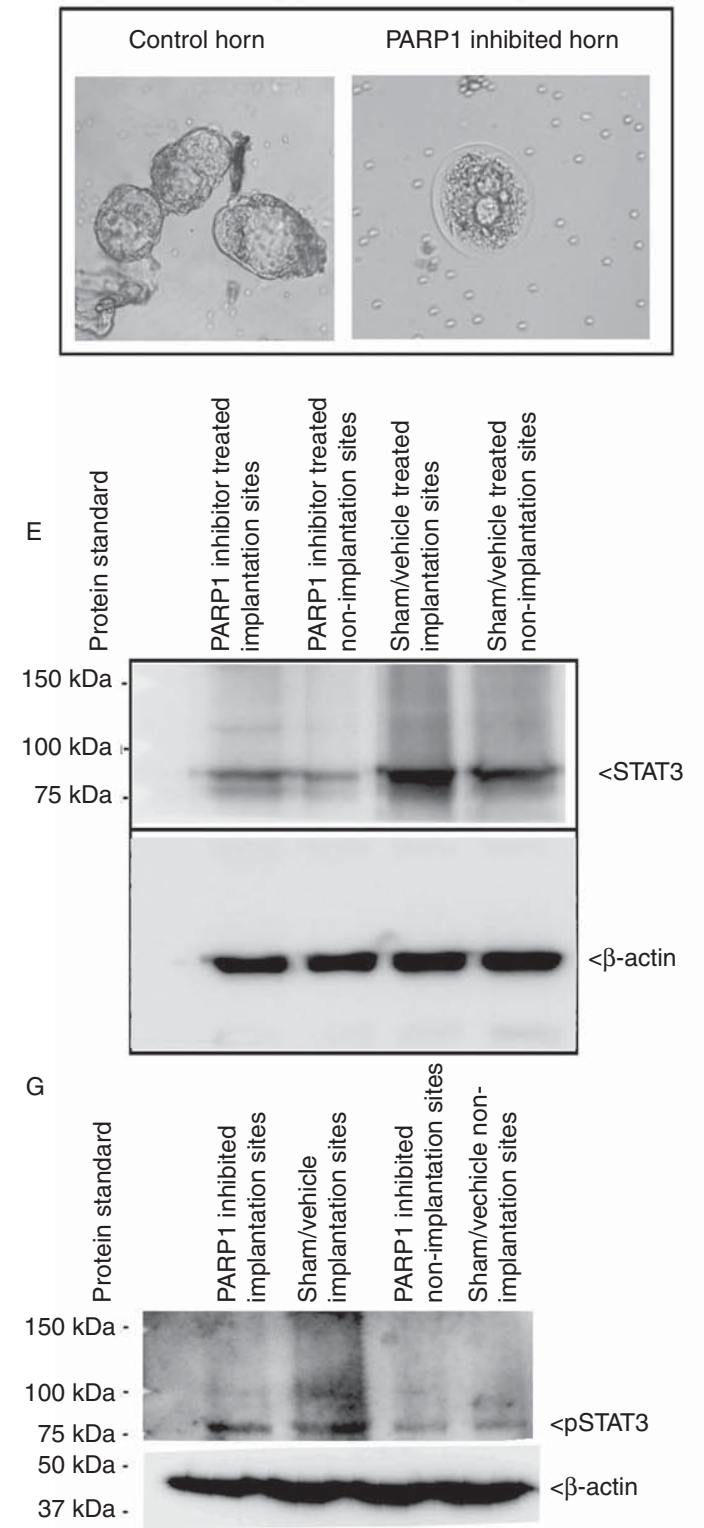

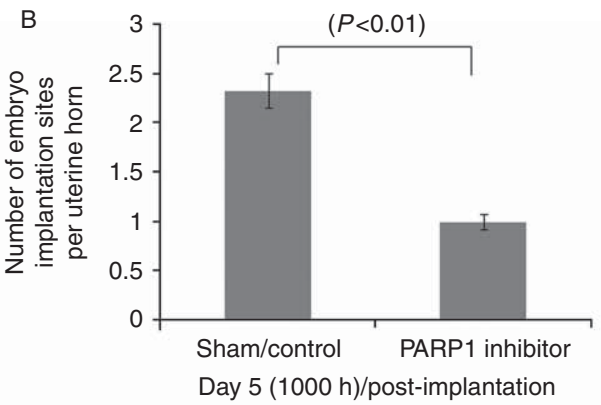

D

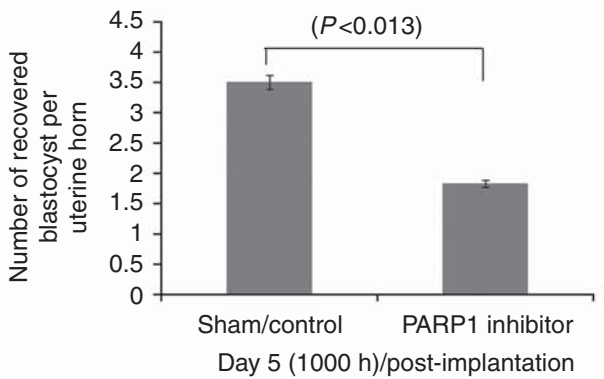

F

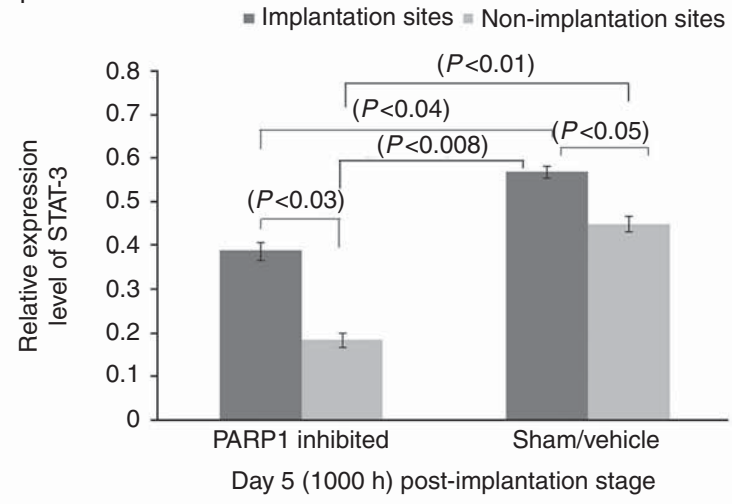

$\mathrm{H}$

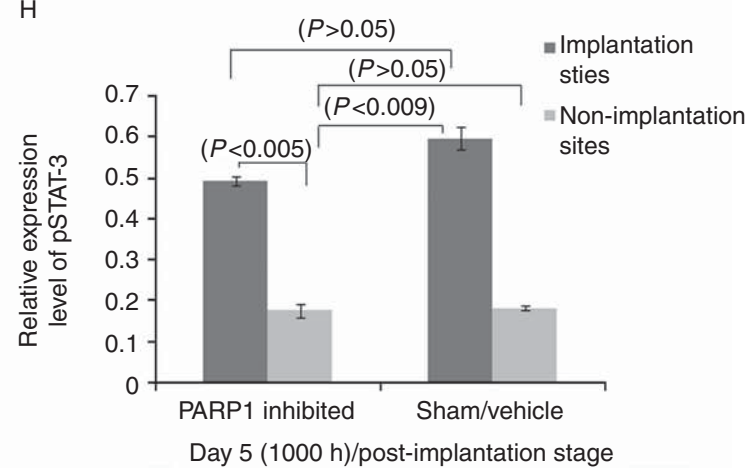

Figure 5 Effect of inhibition of PARP1 on embryo implantation sites. The role of PARP1 at embryo implantation sites at day 5 (1000 h) was studied by administering an inhibitor at day 4 (1000 h) (A, B, C, D). Further, the response of PARP1 inhibition to STAT3 signalling was determined by measuring the expression levels of both total STAT3 and its phosphorylated form (E, F, G, H). 


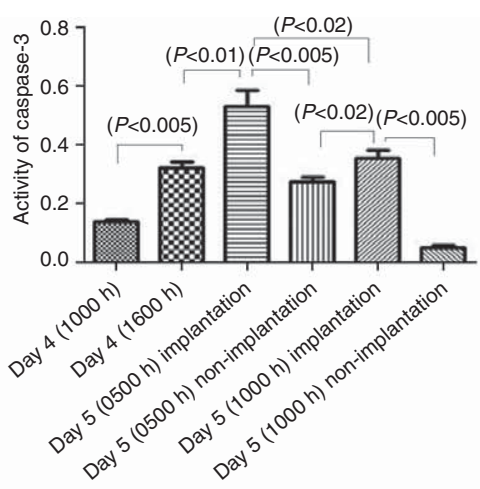

C
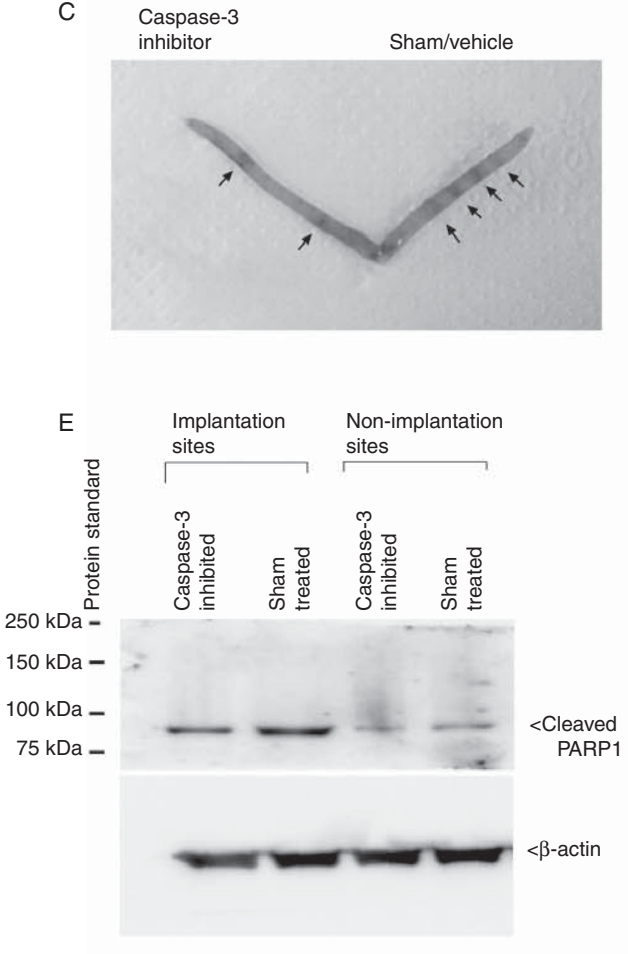

G

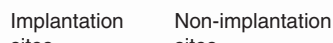

sites sites

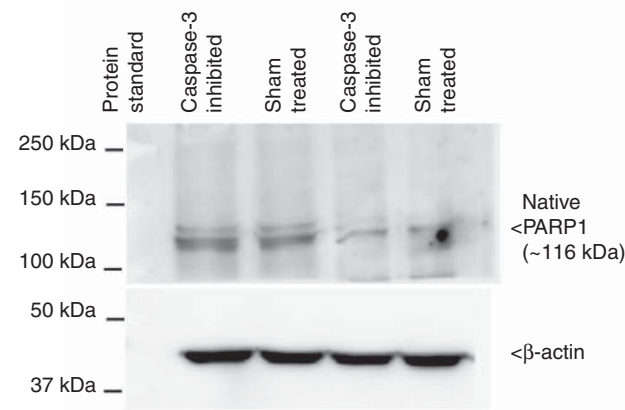

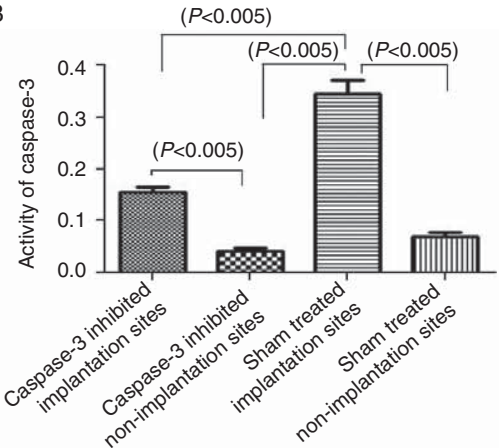

Post-implantation stage day 5 (1000 h)

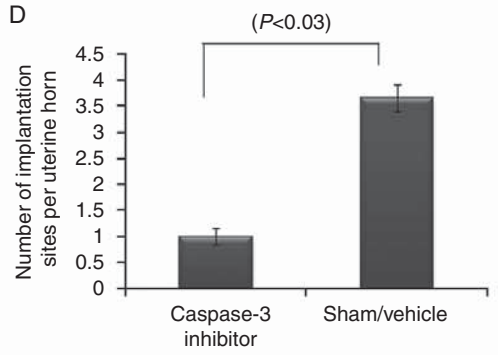

Day 5 (1000 h)/post-implantation stage

F

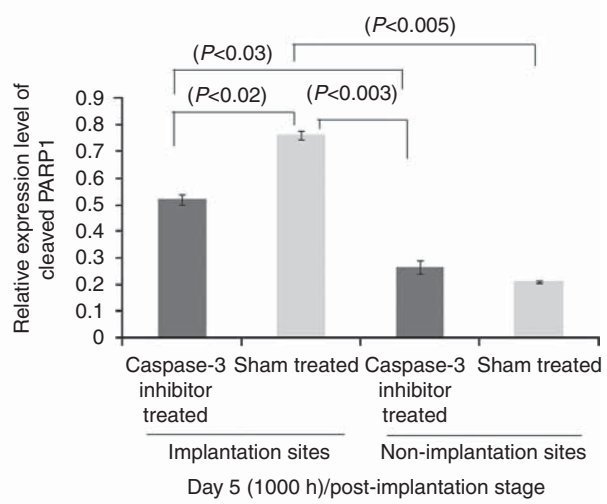

$\mathrm{H}$

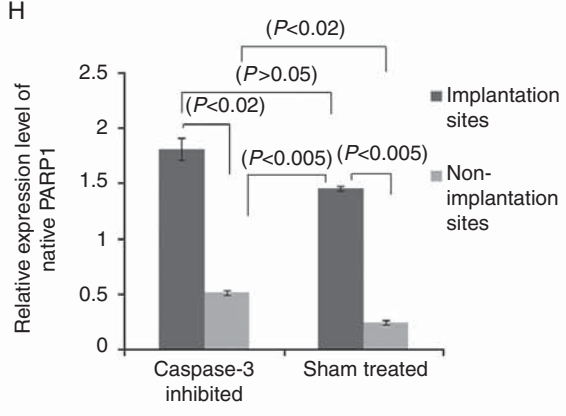

Day 5 (1000 h)/post-implantation stage

Figure 6 Analysis of PARP1 cleavage and embryo implantation sites in response to caspase- 3 inhibition. Activity of caspase- 3 was determined in the uterus during different stages of embryo implantation (A). Further, the activity of caspase- 3 was evaluated in the uterus after inhibition on day 4 $(1000 \mathrm{~h})(\mathrm{B})$. Inhibition of caspase-3 reduced the number of embryo implantation sites (C and D). Additionally, immunoblot analysis of cleaved PARP1 was done following caspase- 3 inhibition at day 5 (1000 h) (E and F). The expression level of native PARP1 (116 kDa) was analysed at day 5 $(1000 \mathrm{~h})$, after caspase-3 treatment $(\mathrm{G}$ and $\mathrm{H})$. 
implantation sites $(P<0.02)$ compared with the shamtreated group. The intensity of the band due to the cleaved form of PARP1 from the non-implantation sites was reduced for the sham-treated as well as caspase-3-treated uterus groups $(P<0.005$; Fig. $6 \mathrm{E}$ and $\mathrm{F})$. Expression of the native form of PARP1 was unaffected at the implantation sites of sham-treated and PARP1 inhibitor-treated uterus, but higher than at the non-implantation sites of the respective groups (Fig. $6 \mathrm{G}$ and $\mathrm{H}$ ).

\section{Hormonal regulation of PARP1 and caspase-3 expression during delayed embryo implantation}

Establishment of the receptive uterus to support embryo development and implantation is primarily coordinated by ovarian hormones, which modulate uterine events in a spatiotemporal manner. Oestrogen and progesterone prime the uterus for implantation (Dey et al. 2004); thus, these ovarian steroid hormones are the key factors influencing embryo implantation. Expression of the native form of PARP1 was found to be low in the progesterone-treated uterine group (Fig. 7A and B). It showed a sudden increase in expression in the progesterone primed oestradiol group $(P<0.03)$ (Fig. 7A and B). The cleaved form of PARP1 was assayed in the uterus treated with progesterone alone and in combination with oestradiol. Progesterone treatment gave a lower level of cleaved PARP1 (Fig. 7C and D), but this level was elevated on supplementation with oestradiol $(P<0.001$; Fig. 7C and D). Additionally, the expression levels of pro-caspase- 3 and active caspase-3 (p17) were found to follow the same pattern as PARP1, showing significant increase in the progesterone $+17 \beta$ oestradiol groups $(P<0.01$ and $P<0.006$ respectively) (Fig. 7E and F).

\section{Discussion}

Remodelling of the uterus for embryo implantation during the female reproductive cycle involves epithelial cell and endometrial gland proliferation (Sato et al. 1997, Fazleabas \& Strakova 2002, Maruyama \& Yoshimura 2008, Tanaka et al. 2009) along with the apoptosis (Joswig et al. 2003). Various other factors also come into the picture, including caspase-3 (Joswig et al. 2003), which is a known upstream molecule in the signalling of PARP1 (Tewari et al. 1995). In our study, the expression level of PARP1 was moderate in pre- and late pre-implantation stages (day 4 (1000 and $1600 \mathrm{~h}$ )), when the uterus is non-receptive and undergoes various changes at the molecular and cellular level in order to become receptive. At the peri-implantation stage, the expression level of native PARP1 was elevated at implantation sites, which suggests a requirement for native PARP1 in the implantation compartment during blastocyst/embryo implantation. This was followed by downregulation of PARP1 at the post-implantation stage (at implantation as well as non-implantation sites). In addition, the cleaved form of PARP1 was also comparatively elevated during late pre- and peri-implantation stages, which suggests a significant role of PARP1 in the process of embryo implantation, in particular at day 5 (0500 h).

As PARP1 is required for various nucleus related functions; we examined its native form in the uterine nuclear compartment at the different stages of embryo implantation. An elevated expression level of nuclear native PARP1 was found at implantation and nonimplantation sites at day $5(0500 \mathrm{~h})$. Interestingly, the cleaved form of PARP1 showed the same pattern as the native form, its expression being elevated at during day 4 $(1600 \mathrm{~h})$ and day 5 (0500 h) (implantation sites). This suggests a requirement for native PARP1 in the nuclear compartment in order for embryo implantation to occur; moreover, cleavage of PARP1 inevitably also takes place in the uterus during embryo implantation. Increased expression of Parp1 transcript during day 5 (0500 h), as evidenced by PCR and real-time PCR, might possibly maintain the equilibrium between the native and cleaved form of PARP1 in the nucleus due to supply of new transcript. Having looked at cleaved PARP1, we investigated the enzyme that cleaves PARP1, caspase-3, in the endometrium during embryo implantation. Elevated activity of caspase-3 was seen at the site of embryo implantation at day $5(0500 \mathrm{~h})$, along with the cleaved form of PARP1. Interestingly, inhibition of caspase-3 activity reduced the number of embryo implantation sites along with the decrease of PARP1 cleavage during the post-implantation period. These results confirm the role of PARP1 during embryo implantation and the requirement for its cleavage by caspase-3 during this phase.

To facilitate embryo implantation, the uterus undergoes decidualisation during the process of embryo invasion from day $5(1000 \mathrm{~h})$ onwards (Carson et al. 2000). It is well-known that the uterine epithelium undergoes remodelling at the site of the implanting embryo/blastocyst (Schlafke et al. 1985, Welsh \& Enders 1991, Ramathal et al. 2011, Estella et al. 2012). The proliferating stromal cells differentiate to form the uterine interface with the placenta, which is referred to as the decidua (Bell 1983), and decidualisation is essential for successful reproduction (Lydon et al. 1995, Robb et al. 1998). PARP1 is reported to be linked with the tissue remodelling process (Pagano et al. 2007). Thus, we examined its possible involvement in the decidualisation of the uterus. The expression level of the native form of PARP1 ( $\sim 116 \mathrm{kDa})$ was on the higher side in the decidualised uterus, along with its cleaved form. This cleavage of PARP1 is possibly mediated by caspase-3 as an elevated expression level of the active form coincided with the level of cleaved PARP1, which suggests that the cleavage of PARP1 is due to the action of caspase- 3 in the decidualised uterus. This is a totally 
A

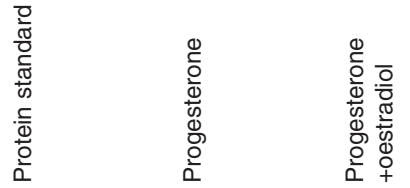

B
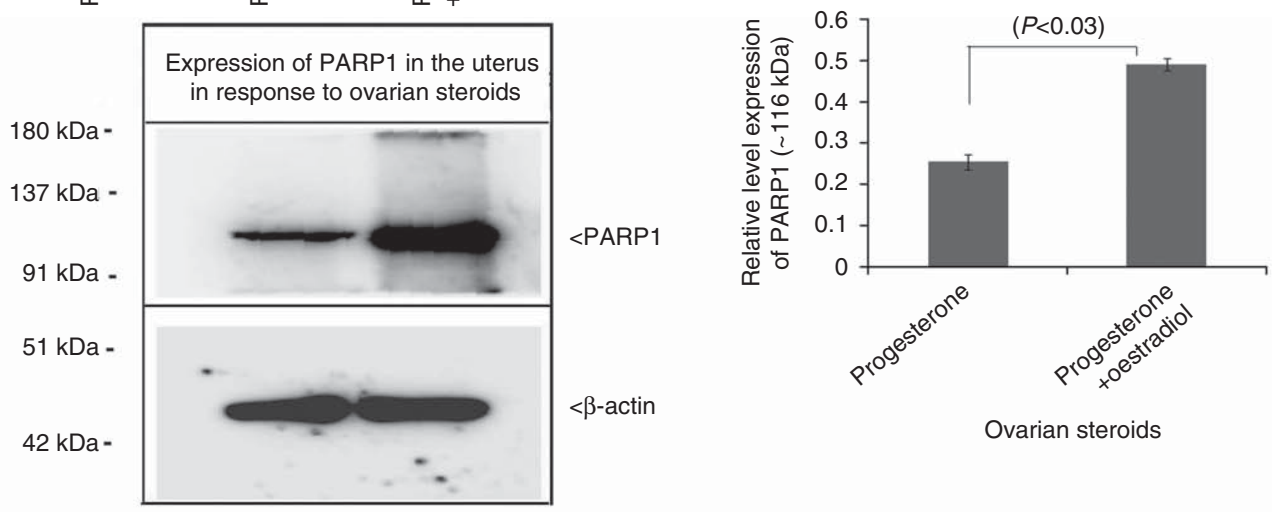

Ovarian steroids

C
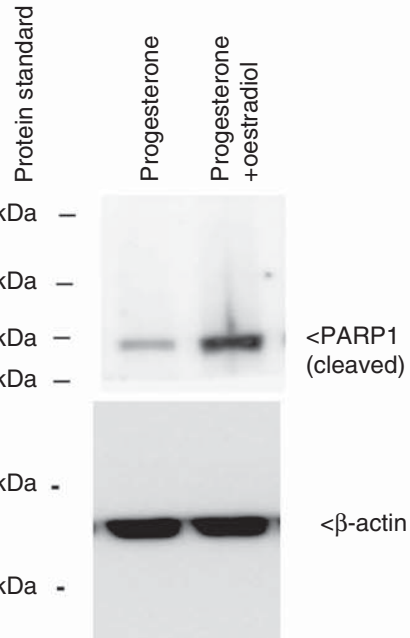

D

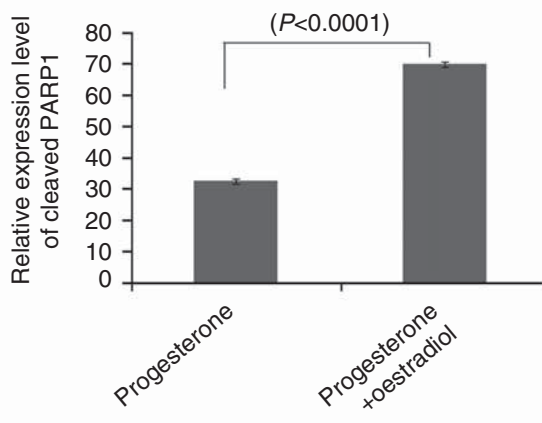

$42 \mathrm{kDa}$ -

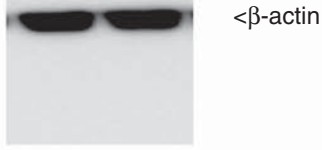

Steroids administered

E

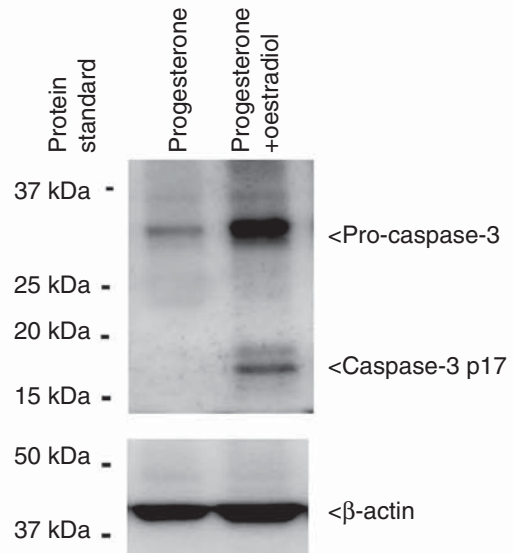

F

- Progesterone $=$ Progesterone+oestradiol

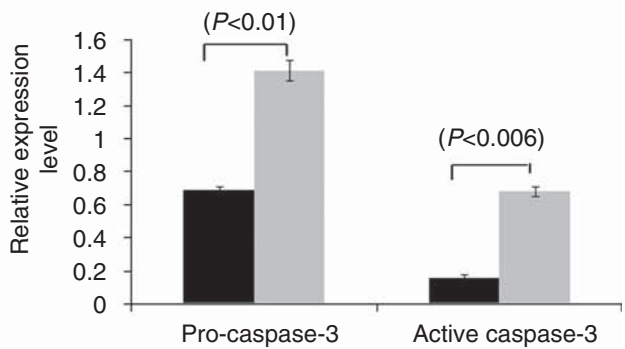

Figure 7 Role of ovarian hormones in regulation of PARP1 expression using delayed embryo implantation. The expression of native/full length/parental forms of PARP1 in response to progesterone and progesterone + oestradiol treatment was measured (A and B). The expression levels of cleaved PARP1, pro- and active caspase-3 (p17) in the pregnant uterus after progesterone and progesterone + oestradiol treatment were also determined (C, D, E and F). $\beta$-actin was used to normalise PARP1 and caspase-3 densitometric values. 
new observation of PARP1 signalling in uterine tissue associated with embryo implantation. This observation does not necessarily mean that PARP1 is required for decidualisation, but clearly indicates a role in this process. Further studies are required to elucidate the exact signalling mechanism of PARP1 in decidualisation.

We next determined the functional role of PARP1 in embryo implantation. Administration of PARP1 inhibitor at the pre-implantation stage blocked embryo implantation at day $5(1000 \mathrm{~h})$ and reduced the number of blastocysts recovered. Furthermore, it also affected the signalling of the embryo implantation associated the gene Stat3. Inhibition of PARP1 downregulated the expression of STAT3 and its activated form (p-STAT3) at day $5(1000 \mathrm{~h})$. This clearly suggests an important role of PARP1 in the embryo implantation process. It is important to note that many previous studies have hinted at a role of PARP1 in endometrial carcinomas (Brustmann 2007, Postawski et al. 2011) and preeclampsia (Crocker et al. 2005), but our study for the first time clearly demonstrates an upregulation of PARP1 in the uterus during the window of uterine receptivity for embryo implantation, functional blockage of which can result in failure to develop embryo implantation sites, suggesting an essential role of PARP1 in embryo implantation or maintenance of uterine receptivity. Further, cleavage of PARP1 is equally important; this is controlled by the action of caspase- 3 in the endometrium, as the blockage of caspase-3 action reduced embryo implantation. The action of caspase-3 during embryo implantation has already been demonstrated (Zhang \& Paria 2006); however, we found that its activity was elevated at implantation sites during the periimplantation stage. Thus, the cleavage of PARP1 by caspase- 3 takes place during embryo implantation, and is essential in this process.

Ovarian steroids play a vital role in uterine tissue during the female reproductive cycle and make the uterus receptive for embryo implantation (Paulson 2011). In mice, implantation of embryos depends on an ovarian oestrogen surge that occurs in the morning of day 4 (1000-1200 h; Yoshinaga \& Adams 1966; McCormack \& Greenwald 1974). PARP1 has been shown to regulate the progesterone receptor in endometrial carcinoma (Ghabreau et al. 2004). To evaluate whether PARP1 expression is modulated by the ovarian steroids progesterone and oestrogen, we selected a delayed implantation mouse model. We ovariectomised the pregnant female mice on day $3(1600 \mathrm{~h})$, before the oestrogen surge, and supplied either progesterone alone or a mix of progesterone and oestrogen to the animal (delayed implantation mice model). Administration of progesterone alone gave a moderate level of PARP1, but this level was elevated in the progesterone-primed oestradiol-treated uterus. Our delayed implantation model clearly suggests that the upregulation of PARP1 expression is an oestradiol-dependent mechanism.
Surprisingly, the cleaved form of PARP1 replicated the pattern of the native form in the progesterone and progesterone $+17 \beta$-oestradiol-treated groups. Furthermore, the increased expression level of active caspase-3 in response to progesterone in combination with oestradiol indicates a role in the cleavage of PARP1.

The picture emerging from this study underlines an important role of PARP1 in the preparation of the uterus for embryo implantation and decidualisation, and PARP1 is cleaved by the action of caspase- 3 at day 5 (0500 h). Our findings unveil for the first time a possible role of PARP1 in the uterus during the window of embryo implantation and decidualisation; it is too soon to define the exact signalling role of PARP1 in the female reproductive cycle, but our study indicates that it is an important one.

\section{Declaration of interest}

The authors declare that there is no conflict of interest that could be perceived as prejudicing the impartiality of the research reported.

\section{Funding}

The present study is supported in part by a grant from ICMR, New Delhi (5/10/10/2011-RHN), and CSIR, New Delhi (BSC0101). A Joshi received a fellowship from the UGC New Delhi, India via sanction no. 2-19/98, date 7 July 2011.

\section{Acknowledgements}

The authors would like to acknowledge the use of the laboratory facilities of Drs Debyendu Banerji, Kumaravelu Jagavelu and Anila Dwivedi. We thank Drs Sripathi Rao Kulkarni and J V Pratap for critical reading of the manuscript. The CSIR-CDRI manuscript communication number is 8615 .

\section{References}

Afshar Y, Jeong JW, Roqueiro D, DeMayo F, Lydon J, Radtke F, Radnor R, Miele L \& Fazleabas A 2012 Notch1 mediates uterine stromal differentiation and is critical for complete decidualization in the mouse. FASEB Journal 26 282-294. (doi:10.1096/fj.11-184663)

Bell SC 1983 Decidualization and associated cell types: implications for the role of the placental bed in the materno-fetal immunological relationship. Journal of Reproductive Immunology 5 185-194. (doi:10.1016/ 0165-0378(83)90234-6)

Brustmann H 2007 Poly(ADP-ribose) polymerase (PARP) and DNAfragmentation factor (DFF45): expression and correlation in normal, hyperplastic and neoplastic endometrial tissues. Pathology, Research and Practice 203 65-72. (doi:10.1016/j.prp.2006.12.003)

Burghardt RC, Johnson GA, Jaeger LA, Ka H, Garlow JE, Spencer TE \& Bazer FW 2002 Integrins and extracellular matrix proteins at the maternal-fetal interface in domestic animals. Cells, Tissues, Organs 172 202-217. (doi:10.1159/000066969)

Carson DD, Bagchi I, Dey SK, Enders AC, Fazleabas AT, Lessey BA \& Yoshinaga K 2000 Embryo implantation. Developmental Biology 223 217-237. (doi:10.1006/dbio.2000.9767) 
Correia-da-Silva G, Bell SC, Pringle JH \& Teixeira NA 2004 Patterns of uterine cellular proliferation and apoptosis in the implantation site of the rat during pregnancy. Placenta 25 538-547. (doi:10.1016/j.placenta. 2003.11.007)

Crocker IP, Kenny LC, Thornton WA, Szabo C \& Baker PN 2005 Excessive stimulation of poly(ADP-ribosyl)ation contributes to endothelial dysfunction in pre-eclampsia. British Journal of Pharmacology 144 772-780. (doi:10.1038/sj.bjp.0706055)

Davoodi-Semiromi A, Laloraya M, Kumar GP, Purohit S, Jha RK \& She JX 2004 A mutant Stat5b with weaker DNA binding affinity defines a key defective pathway in nonobese diabetic mice. Journal of Biological Chemistry 279 11553-11561. (doi:10.1074/jbc.M312110200)

Demir R, Kayisli UA, Celik-Ozenci C, Korgun ET, Demir-Weusten AY \& Arici A 2002 Structural differentiation of human uterine luminal and glandular epithelium during early pregnancy: an ultrastructural and immunohistochemical study. Placenta 23 672-684. (doi:10.1053/plac. 2002.0841)

Dey SK, Lim H, Das SK, Reese J, Paria BC, Daikoku T \& Wang H 2004 Molecular cues to implantation. Endocrine Reviews 25 341-373. (doi:10.1210/er.2003-0020)

Duc-Goiran P, Mignot TM, Bourgeois C \& Ferre F 1999 Embryo-maternal interactions at the implantation site: a delicate equilibrium. European Journal of Obstetrics, Gynecology, and Reproductive Biology 83 85-100. (doi:10.1016/S0301-2115(98)00310-8)

Enders AC 2000 Trophoblast-uterine interactions in the first days of implantation: models for the study of implantation events in the human. Seminars in Reproductive Medicine 18 255-263. (doi:10.1055/s-200012563)

Estella C, Herrer I, Atkinson SP, Quinonero A, Martinez S, Pellicer A \& Simon C 2012 Inhibition of histone deacetylase activity in human endometrial stromal cells promotes extracellular matrix remodelling and limits embryo invasion. PLoS ONE 7 e30508. (doi:10.1371/journal.pone. 0030508)

Fazleabas AT \& Strakova Z 2002 Endometrial function: cell specific changes in the uterine environment. Molecular and Cellular Endocrinology 186 143-147. (doi:10.1016/S0303-7207(01)00655-4)

Ghabreau L, Roux JP, Frappart PO, Mathevet P, Patricot LM, Mokni M, Korbi S, Wang ZQ, Tong WM \& Frappart L 2004 Poly(ADP-ribose) polymerase-1, a novel partner of progesterone receptors in endometrial cancer and its precursors. International Journal of Cancer 109 317-321. (doi:10.1002/ijc.11731)

Huang D, Wang Y, Wang L, Zhang F, Deng S, Wang R, Zhang Y \& Huang K 2011 Poly(ADP-ribose) polymerase 1 is indispensable for transforming growth factor $\beta$ Induced Smad3 activation in vascular smooth muscle cell. PLOS ONE 6 e27123. (doi:10.1371/journal.pone.0027123)

Ittner LM \& Gotz J 2007 Pronuclear injection for the production of transgenic mice. Nature Protocols 2 1206-1215. (doi:10.1038/nprot. 2007.145)

Jagtap PG, Southan GJ, Baloglu E, Ram S, Mabley JG, Marton A, Salzman A \& Szabo C 2004 The discovery and synthesis of novel adenosine substituted 2,3-dihydro- $1 \mathrm{H}$-isoindol-1-ones: potent inhibitors of poly (ADP-ribose) polymerase-1 (PARP-1). Bioorganic and Medicinal Chemistry Letters 14 81-85. (doi:10.1016/j.bmcl.2003.10.007)

Jha RK, Titus S, Saxena D, Kumar PG \& Laloraya M 2006 Profiling of E-cadherin, $\beta$-catenin and $\mathrm{Ca}^{2+}$ in embryo-uterine interactions at implantation. FEBS Letters 580 5653-5660. (doi:10.1016/j.febslet.2006. 09.014)

Joswig A, Gabriel HD, Kibschull M \& Winterhager E 2003 Apoptosis in uterine epithelium and decidua in response to implantation: evidence for two different pathways. Reproductive Biology and Endocrinology 144. (doi:10.1186/1477-7827-1-44)

Kaloglu C \& Onarlioglu B 2010 Extracellular matrix remodelling in rat endometrium during early pregnancy: the role of fibronectin and laminin. Tissue Cell 42 301-306. (doi:10.1016/j.tice.2010.07.004)

Kauppinen TM, Gan L \& Swanson RA 2013 Poly(ADP-ribose) polymerase1 -induced $\mathrm{NAD}^{+}$depletion promotes nuclear factor- $\mathrm{KB}$ transcriptional activity by preventing p65 de-acetylation. Biochimica et Biophysica Acta 1833 1985-1991. (doi:10.1016/j.bbamcr.2013.04.005)

Kennedy TG, Gillio-Meina C \& Phang SH 2007 Prostaglandins and the initiation of blastocyst implantation and decidualization. Reproduction 134 635-643. (doi:10.1530/REP-07-0328)
Kobayashi T 2011 Suppression of matrix metalloproteinase-9 expression in undifferentiated, non-apoptotic keratinocytes is abrogated by the cleavage of poly(ADP-ribose) polymerase-1. Apoptosis 16 1205-1216. (doi:10.1007/s10495-011-0650-9)

Kondoh E, Okamoto T, Higuchi T, Tatsumi K, Baba T, Murphy SK, Takakura K, Konishi I \& Fujii S 2009 Stress affects uterine receptivity through an ovarian-independent pathway. Human Reproduction $\mathbf{2 4}$ 945-953. (doi:10.1093/humrep/den461)

Lacal PM, Tentori L, Muzi A, Ruffini F, Dorio AS, Xu W, Arcelli D, Zhang J \& Graziani G 2009 Pharmacological inhibition of poly(ADP-ribose) polymerase activity down-regulates the expression of syndecan-4 and Id-1 in endothelial cells. International Journal of Oncology 34 861-872. (doi:10.3892/ijo_00000213)

Laemmli UK 1970 Cleavage of structural proteins during the assembly of the head of bacteriophage T4. Nature 227 680-685. (doi:10.1038/ 227680a0)

Laemmli UK, Beguin F \& Gujer-Kellenberger G 1970 A factor preventing the major head protein of bacteriophage T4 from random aggregation. Journal of Molecular Biology 47 69-85. (doi:10.1016/0022-2836(70) 90402-X)

Lee JE, Oh HA, Song H, Jun JH, Roh CR, Xie H, Dey SK \& Lim HJ 2011 Autophagy regulates embryonic survival during delayed implantation. Endocrinology 152 2067-2075. (doi:10.1210/en.2010-1456)

Lei CX, Zhang W, Zhou JP \& Liu YK 2009 Interactions between galectin-3 and integrin $\beta 3$ in regulating endometrial cell proliferation and adhesion. Human Reproduction 24 2879-2889. (doi:10.1093/humrep/dep250)

Lei W, Feng XH, Deng WB, Ni H, Zhang ZR, Jia B, Yang XL, Wang TS, Liu JL, Su RW et al. 2012 Progesterone and DNA damage encourage uterine cell proliferation and decidualization through up-regulating ribonucleotide reductase 2 expression during early pregnancy in mice. Journal of Biological Chemistry 287 15174-15192. (doi:10.1074/jbc.M111. 308023)

Lin HY, Qian D, Zhang X, Liu GY, Wang HM \& Zhu C 2006 Gene expression of transforming growth factor- $\beta$ receptors types I and II in rat endometrium during the estrous cycle and early pregnancy. Life Science 78 2669-2675. (doi:10.1016/j.Ifs.2005.10.012)

Lin Y, Tang X, Zhu Y, Shu T \& Han X 2011 Identification of PARP-1 as one of the transcription factors binding to the repressor element in the promoter region of COX-2. Archives of Biochemistry and Biophysics 505 123-129. (doi:10.1016/j.abb.2010.09.016)

Livak KJ \& Schmittgen TD 2001 Analysis of relative gene expression data using real-time quantitative PCR and the $2^{-\Delta \Delta C_{\mathrm{T}}}$ method. Methods 25 402-408. (doi:10.1006/meth.2001.1262)

Lydon JP, DeMayo FJ, Funk CR, Mani SK, Hughes AR, Montgomery CA Jr, Shyamala G, Conneely OM \& O'Malley BW 1995 Mice lacking progesterone receptor exhibit pleiotropic reproductive abnormalities. Genes and Development 9 2266-2278. (doi:10.1101/gad.9.18.2266)

Macdonald LJ, Sales KJ, Grant V, Brown P, Jabbour HN \& Catalano RD 2011 Prokineticin 1 induces Dickkopf 1 expression and regulates cell proliferation and decidualization in the human endometrium. Molecular Human Reproduction 17 626-636. (doi:10.1093/molehr/gar031)

Maruyama T \& Yoshimura Y 2008 Molecular and cellular mechanisms for differentiation and regeneration of the uterine endometrium. Endocrine Journal 55 795-810. (doi:10.1507/endocrj.K08E-067)

Maurya VK, Jha RK, Kumar V, Joshi A, Chadchan S, Mohan JJ \& Laloraya M 2013 Transforming growth factor- $\beta 1$ (TGF- $\beta$ ) liberation from its latent complex during embryo implantation and its regulation by estradiol in mouse. Biology of Reproduction 89 84. (doi:10.1095/biolreprod.112. 106542)

McCormack JT \& Greenwald GS 1974 Evidence for a preimplantation rise in oestradiol- $17 \beta$ levels on day 4 of pregnancy in the mouse. Journal of Reproduction and Fertility 41 297-301. (doi:10.1530/jrf.0.0410297)

McPhee TR, McDonald PC, Oloumi A \& Dedhar S 2008 Integrin-linked kinase regulates E-cadherin expression through PARP-1. Developmental Dynamics 237 2737-2747. (doi:10.1002/dvdy.21685)

Menisser-de MJ, Mark M, Wendling $O$, Wynshaw-Boris A \& de Murcia G 2001 Early embryonic lethality in PARP-1 Atm double-mutant mice suggests a functional synergy in cell proliferation during development. Molecular and Cellular Biology 21 1828-1832. (doi:10.1128/MCB.21.5. 1828-1832.2001)

Musard JF, Sallot M, Dulieu P, Fraichard A, Ordener C, Remy-Martin JP, Jouvenot M \& Adami P 2001 Identification and expression of a new 
sulfhydryl oxidase SOx-3 during the cell cycle and the estrus cycle in uterine cells. Biochemical and Biophysical Research Communications 287 83-91. (doi:10.1006/bbrc.2001.5440)

Nakamura H, Kimura T, Ogita K, Nakamura T, Takemura M, Shimoya K, Koyama S, Tsujie T, Koyama M \& Murata Y 2004 NF-KB activation at implantation window of the mouse uterus. American Journal of Reproductive Immunology 51 16-21. (doi:10.1046/j.8755-8920.2003.00116.x)

Nakamura H, Kimura T, Koyama S, Ogita K, Tsutsui T, Shimoya K, Taniguchi T, Koyama M, Kaneda Y \& Murata Y 2006 Mouse model of human infertility: transient and local inhibition of endometrial STAT-3 activation results in implantation failure. FEBS Letters $\mathbf{5 8 0} 2717-2722$. (doi:10.1016/j.febslet.2006.04.029)

Pagano A, Metrailler-Ruchonnet I, Aurrand-Lions M, Lucattelli M, Donati Y \& Argiroffo CB 2007 Poly(ADP-ribose) polymerase-1 (PARP-1) controls lung cell proliferation and repair after hyperoxia-induced lung damage. American Journal of Physiology. Lung Cellular and Molecular Physiology 293 L619-L629. (doi:10.1152/ajplung.00037.2007)

Pakrasi PL \& Jain AK 2008 Cyclooxygenase-2-derived endogenous prostacyclin reduces apoptosis and enhances embryo viability in mouse. Prostaglandins, Leukotrienes, and Essential Fatty Acids 79 27-33. (doi:10.1016/j.plefa.2008.07.006)

Pampfer S \& Donnay I 1999 Apoptosis at the time of embryo implantation in mouse and rat. Cell Death and Differentiation 6 533-545. (doi:10.1038/ sj.cdd.4400516)

Paria BC, Huet-Hudson YM \& Dey SK 1993 Blastocyst's state of activity determines the "window" of implantation in the receptive mouse uterus. PNAS 90 10159-10162. (doi:10.1073/pnas.90.21.10159)

Paulson RJ 2011 Hormonal induction of endometrial receptivity. Fertility and Sterility 96 530-535. (doi:10.1016/j.fertnstert.2011.07.1097)

Postawski K, Monist M \& Keith G 2011 PARP-1 activity in normal and cancerous human endometrium and its relationship with quantity of abasic sites (AP). Ginekologia Polska 82 16-21.

Psychoyos A 1986 Uterine receptivity for nidation. Annals of the New York Academy of Sciences 476 36-42. (doi:10.1111/j.1749-6632.1986. tb20920.x)

Ramathal C, Wang W, Hunt E, Bagchi IC \& Bagchi MK 2011 Transcription factor CCAAT enhancer-binding protein $\beta(C / E B P \beta)$ regulates the formation of a unique extracellular matrix that controls uterine stromal differentiation and embryo implantation. Journal of Biological Chemistry 286 19860-19871. (doi:10.1074/jbc.M110.191759)

Robb L, Li R, Hartley L, Nandurkar HH, Koentgen F \& Begley CG 1998 Infertility in female mice lacking the receptor for interleukin 11 is due to a defective uterine response to implantation. Nature Medicine 4 303-308. (doi:10.1038/nm0398-303)

Rosario G, Sachdeva G, Okulicz WC, Ace Cl, Katkam RR \& Puri CP 2003 Role of progesterone in structural and biochemical remodeling of endometrium. Frontiers in Bioscience 8 s924-s935. (doi:10.2741/1173)

San MS, Soto-Suazo M \& Zorn TM 2004 Perlecan and syndecan-4 in uterine tissues during the early pregnancy in mice. American Journal of Reproductive Immunology 52 53-59. (doi:10.1111/j.1600-0897.2004.00182.x)

Sato T, Fukazawa Y, Kojima H, Enari M, Iguchi T \& Ohta Y 1997 Apoptotic cell death during the estrous cycle in the rat uterus and vagina. Anatomical Record 248 76-83. (doi:10.1002/(SICI)1097-0185(199705) 248:1 < 76::AID-AR9 > 3.0.CO;2-D)

Schlafke S, Welsh AO \& Enders AC 1985 Penetration of the basal lamina of the uterine luminal epithelium during implantation in the rat. Anatomical Record 212 47-56. (doi:10.1002/ar.1092120107)
Spina-Purrello V, Giliberto S, Barresi V, Nicoletti VG, Giuffrida Stella AM \& Rizzarelli E 2010 Modulation of PARP-1 and PARP-2 expression by L-carnosine and trehalose after LPS and INF $\gamma$-induced oxidative stress. Neurochemical Research 35 2144-2153. (doi:10.1007/s11064-0100297-x)

Sterling JA, Wu L \& Banerji SS 2006 PARP regulates TGF- $\beta$ receptor type II expression in estrogen receptor-positive breast cancer cell lines. Anticancer Drugs 26 1893-1901.

St-Louis I, Singh M, Brasseur K, Leblanc V, Parent S \& Asselin E 2010 Expression of COX-1 and COX-2 in the endometrium of cyclic, pregnant and in a model of pseudopregnant rats and their regulation by sex steroids. Reproduction Biology and Endocrinology 8 103. (doi:10.1186/ 1477-7827-8-103)

Suzuki H, Tornese BD \& Weisz A 1990 Inverse relationship between poly (ADP-ribose) polymerase activity and $2^{\prime}, 5^{\prime}$-oligoadenylates core level in estrogen-treated immature rat. Molecular and Cellular Biochemistry 99 33-39. (doi:10.1007/BF01261391)

Tanaka T, Wang C \& Umesaki N 2009 Remodeling of the human endometrial epithelium is regulated by laminin and type IV collagen. International Journal of Molecular Medicine 23 173-180. (doi:10.3892/ ijmm_00000147)

Tewari $M$, Quan LT, O'Rourke K, Desnoyers S, Zeng Z, Beidler DR, Poirier GG, Salvesen GS \& Dixit VM 1995 Yama/CPP32 $\beta$, a mammalian homolog of CED-3, is a CrmA-inhibitable protease that cleaves the death substrate poly(ADP-ribose) polymerase. Cell 81 801-809. (doi:10.1016/ 0092-8674(95)90541-3)

Towbin H, Staehelin T \& Gordon J 1992 Electrophoretic transfer of proteins from polyacrylamide gels to nitrocellulose sheets: procedure and some applications. 1979. Biotechnology 24 145-149.

von Lukowicz T, Hassa PO, Lohmann C, Boren J, Braunersreuther V, Mach F, Odermatt B, Gersbach M, Camici GG, Stahli BE et al. 2008 PARP1 is required for adhesion molecule expression in atherogenesis. Cardiovascular Research 78 158-166. (doi:10.1093/cvr/cvm110)

Watzlawik J, Holicky E, Edberg DD, Marks DL, Warrington AE, Wright BR, Pagano RE \& Rodriguez M 2010 Human remyelination promoting antibody inhibits apoptotic signaling and differentiation through Lyn kinase in primary rat oligodendrocytes. Glia 58 1782-1793. (doi:10. 1002/glia.21048)

Welsh AO \& Enders AC 1991 Chorioallantoic placenta formation in the rat: I. Luminal epithelial cell death and extracellular matrix modifications in the mesometrial region of implantation chambers. American Journal of Anatomy 192 215-231. (doi:10.1002/aja.1001920302)

Yoshinaga K \& Adams CE 1966 Delayed implantation in the spayed, progesterone treated adult mouse. Journal of Reproduction and Fertility 12 593-595. (doi:10.1530/jrf.0.0120593)

Zhang Q \& Paria BC 2006 Importance of uterine cell death, renewal, and their hormonal regulation in hamsters that show progesterone-dependent implantation. Endocrinology 147 2215-2227. (doi:10.1210/en.2005-1555)

Received 26 November 2013

First decision 23 December 2013

Revised manuscript received 3 February 2014

Accepted 10 February 2014 